\section{IJ§ER}

ISSN: 2149-5939
International Journal of Social Sciences and Education Research

Online, http://dergipark.gov.tr/ijsser

Volume: 3(1), 2017

\title{
Okul öncesi öğretmen adaylarının problem çözme ve sosyal beceri düzeylerinin incelenmesi ${ }^{1}$
}

\author{
Examination of preservice preschool teachers' level of problem solving and so- \\ cial skills
}

Fatma Yaşar Ekici

\begin{abstract}
Received Date: 03 / 09 / 2016
Accepted Date: 12 / $11 / 2016$

$\ddot{O} z$

Bu araştırmanın temel amacı okul öncesi ögretmen adaylarının problem çözme ve sosyal beceri düzeyleri ve bu beceriler arasındaki ilişkiyi incelemektir. Araştırmada ilişkisel tarama modeli kullanılmıştır. Araştırma evrenini İstanbul İlindeki üniversitelerin okul öncesi ögretmenliği programında ögrenim görmekte olan lisans öğrencileri oluşturmaktadır. Araştırma örneklemini ise 2014-2015 bahar yarlyılında İstanbul Sabahattin Zaim Üniversitesi Ĕ̆itim Fakültesi'nde okul öncesi ögretmenliği lisans programında ögrenim görmekte olan ve tesadüfi örnekleme metoduyla seçilen 140 ögrenci oluşturmaktadır. Verilerin toplanmasında araştırmacı tarafindan geliştirilen Kişisel Bilgi Formu, Riggio (1986) tarafindan geliştirilmiş ve Yüksel (2004) tarafindan Türkçeye uyarlanmış olan "Sosyal Beceri Envanteri (SBE)" ve Heppner ve Petersen (1982) tarafindan geliştirilmiş ve Şahin, Şahin ve Heppner (1993) tarafindan Türkçe 'ye uyarlanmış olan "Problem Çözme Envanteri (SBE)" kullanılmıştır. Verilerin analizinde SPSS.20 paket programı kullanılmıştır. Araştırmada elde edilen bulgular şöyledir: okul öncesi öğretmen adaylarının sosyal becerileri yaş, sınıf, ögrenim görürken kalınan yer ve gelir düzeyine göre anlamlı düzeyde farklılaşmaktadır. Bundan farklı olarak, okul öncesi öğretmen adaylarının problem çözme becerileri ile yaş, sınıf, ögrenim görürken kalınan yer, gelir düzeyi ve ailedeki kardeş sayısı değişkenleri arasında anlamlı bir farklılık saptanmamıştır. Okul öncesi ögretmen adaylarının problem çözme becerileri ve sosyal becerileri arasında anlamlı bir ilişki saptanmamıştır.

Anahtar Sözcükler: Okul öncesi ĕgitim, ögretmen adayı, problem çözme becerileri, sosyal beceriler
\end{abstract}

\begin{abstract}
The aim of this research is to examine preservice preschool teachers' level of problem solving and social skills and to investigate relationship between level of problem solving and social skills of preservice preschool teachers. The study was conducted in the "Ilisskisel Tarama" model. The population of the study consists of undergraduate students that are studying in preschool teaching program of universities in Istanbul. The sample of the study consists of 140 undergraduate students that are studying in preschool teaching program of Istanbul Sabahattin Zaim University in 2014-2015 spring period. The sample was selected by random sampling method. The tool used for data collection were "Personal Information Form" that is developed by the researcher, "Social Skills Inventory" that is developed by Riggio (1986) and adopted to Turkish language by Yüksel (2004) and "Problem Solving Inventory" that is developed by Heppner ve Petersen (1982) and adopted to Turkish language by Şahin, Şahin ve Heppner (1993). In the analysis of the data, SPSS 20 package program was applied. At the end of the research, it was found that there is a significant difference between preservice preschool teachers' social skills and age, grade, place stayed during education and income level. Different from that, there is not a significant difference between preservice preschool teachers' problem solving skills and age, grade, place stayed during education and income level, number of sibling. There is not a significant correlation between problem solving skills and social skills of precervice preschool teachers.
\end{abstract}

Keywords: Preschool education, preservice teacher, problem solving skills, social skills.

\footnotetext{
${ }^{1}$ Bu makale, II. Uluslararası Sosyal Bilimler ve Eğitim Araştırmaları Konferansı'nda (04-06 Kasım 2016) sunulan bildirinin gözden geçirilmiş ve genişletilmiş halidir.

${ }^{2}$ Yrd.Doç.Dr., İstanbul Sabahattin Zaim Üniversitesi, Eğitim Fakültesi, Okul Öncesi Öğretmenliği Ana Bilim Dalı, İstanbul, TÜRKIYE, fatmayasarekici@ hotmail.com
} 
Yaşar Ekici, F. (2017). Examination of preservice preschool teachers' level of problem solving and social skills. International Journal of Social Sciences and Education Research, 3(1), 16-38.

\section{Giriş}

Problem çözme bilişsel, duyuşsal ve davranışsal işlemleri içeren bir süreç olarak ifade edilmekte ve problem çözme, iç ya da diş istekler ya da çağrılara uyum sağlamak amacı ile davranışsal tepkilerde bulunma gibi bilişsel ve duyuşsal işlemleri bir hedefe yöneltmek olarak tanımlanmaktadır (Heppner ve Petersen, 1982). Problem çözme, etkili öğrenme ve bireysel yetenekleri geliştirme yoludur (Kaptan ve Korkmaz, 2002). Problem çözme, önceki yaşantılar aracılığı ile yeni çözüm yolları bulabilmeyi (Korkut, 2002) ve bilginin yanı sıra yaratıc1lık ve çözüme ilişkin yöntemlerden yararlanmayı (Yalçın, Tetik ve Açıkgöz, 2010) gerektirmektedir. Problem çözme becerisi ise, bireysel bir değişken olarak görülmekte ve bireyin kendi problem çözme becerisine ilişkin inanç ve beklentilerine dayalı olarak şekillendiği ifade edilmektedir (Heppner, Witty ve Dixon, 2004; Alc1, 2007). Problem çözme çocukluktan itibaren öğrenilmekte, problem çözme becerileri ise okul yıllarında geliştirilmektedir (Serin, 2006, Polat, 2008).Problem çözme becerisine sahip bireyler yaratıcı ve bağımsız düşünebilen, sosyal ve kendine güvenen bireylerdir (Miller ve Nunn, 2001). Kendisini problem çözmede yeterli olarak algılayanların kişilerarası ilişkilerde daha girişken, daha olumlu benlik algısına sahip oldukları ve akademik yönden daha uygun çalışma yöntemleri ve durumları sergiledikleri saptanmıştır (Şahin, Şahin ve Heppner, 1993). Problem çözmede başarılı olan öğrenciler kendilerini, problem çözmeye karşı güdülenmiş ve daha kararlı, dikkatli, sezgili, tutarlı ve sistematik olarak algılamaktadırlar (Heppner, Stephen, Strozier ve Heppner, 1991). Problem çözmede kendisini başarısız olarak değerlendirenlerin, daha fazla iç çatışmalı, kişilerarası ilişkilerde aşırı duyarlı, depresif ve opsesif davranışlara sahip oldukları, düşmanca ve olumsuz davranışlar sergiledikleri ifade edilmektedir (Dixon, Heppner ve Anderson, 1991).

Toplum içerisinde yaşayan birey için başkalarından olumlu tepkiler getirecek ve olumsuz tepkilerin gelmesini önleyecek becerilere sahip olmak ve duygularını, düşüncelerini çevresinde ilişki kurduğu insanlara iletmek oldukça önemlidir. Ayrıca insan kişiler arası iletişim gereği ilişki kurduğu insanların duygularını, düşüncelerini de anlamak ister (Başaran, 1994; Bacanlı, H., 1999; Aydın, G., 1985). Bu da bireyin bir takım becerilere sahip olmasıyla mümkündür. Bu davranışlar genel olarak sosyal beceri olarak adlandırılmaktadır. Sosyal beceriler, başkalarının olumlu tepkiler vermesine yol açabilecek ve olumsuz tepkileri önleyebilecek, başkalarıyla etkileşimi mümkün kılacak sosyal açıdan kabul edilebilir davranışlar olarak da tanımlanmaktadır (Şahin ve Kaya, 2004). Sosyal beceriler bireyin yaşamında önemli bir role sahiptir. Çünkü diğer insanlarla iletişimde bulunmayı kolaylaştırıcı önemli bir özelliktir (Yüksel, 2001 Acar, N., 1980; Akkök, F., 1996; Bacanl1, H., 1990). Sosyal beceriye sahip bireyler sosyal ilişkilerde güvenlidirler. Çünkü bu bireyler sosyal statülerindeki başarılarını dışsal nedenlerden çok içsel nedenlere yüklemişlerdir (Riggio ve diğerleri, 1991). Giblin ve diğerlerine göre (1995) insanların, diğer insanlarla başarılı ilişkiler kurabilmeyi öğrenmesi durumunda, tüm iş kollarında, kariyerde ve uğraş alanlarında işin \% 85'i ve kişisel mutluluk yolunda da işin \% 99'u halledilmiş olacaktır.

Yukarıda verilen bilgiler değerlendirildiğinde görülmektedir ki problem çözme becerileri ile sosyal beceriler birbiriyle yakından ilgili becerilerdir. Öğretmenlik mesleği, çözüm odaklı ve sosyal ilişki temeli üzerine dayalı bir meslektir. Bu mesleği icra edecek olan öğretmen adaylarının kaliteli bir eğitimci olabilmesinin yolu yüksek problem çözme becerisi ve sosyal beceriye sahip olmalarından geçmektedir. Bu çerçevede, okul öncesi öğretmen adaylarının 
Yaşar Ekici, F. (2017). Okul öncesi öğretmen adaylarının problem çözme ve sosyal beceri düzeylerinin incelenmesi. International Journal of Social Sciences and Education Research, 3(1), 16-38.

problem çözme ve sosyal beceri düzeyleri ve bu becerileri arasındaki ilişkiyi incelemek üzere bu araştırma yapılmıştır.

\subsection{Araştırmanın amaç ve alt amaçları}

$\mathrm{Bu}$ araştırmanın temel amacı okul öncesi öğretmen adaylarının problem çözme ve sosyal beceri düzeyleri ve bu beceriler arasındaki ilişkiyi incelemektir.

$\mathrm{Bu}$ temel amaç çerçevesinde belirlenen alt amaçlar şu şekildedir:

- Okul öncesi öğretmen adaylarının problem çözme ve sosyal beceri düzeyleri yaş, sınıf, öğrenim görürken kalınan yer, gelir düzeyi ve ailedeki kardeş sayısına göre farklılaşmakta m1dir?

- Okul öncesi öğretmen adaylarının genel olarak problem çözme beceri düzeyleri ve sosyal beceri düzeyleri arasında anlamlı bir ilişki var mıdır?

\section{Yöntem}

\subsection{Araştırmanın modeli}

$\mathrm{Bu}$ araştırmada, okul öncesi öğretmen adaylarının problem çözme ve sosyal beceri düzeyleri ve bu beceriler arasındaki ilişki incelendiği için tarama modellerinden ilişkisel tarama modeli kullanılmıştır. Tarama modelleri, geçmişte ya da halen var olan bir durumu, var olduğu şekilde betimlemeyi amaçlayan bir araştırma yaklaşımıdır. Tarama modelinin bir türü olan ilişkisel tarama modelinde ise; iki ya da daha çok sayıda değiş̧en arasında birlikte değişim varlığ 1 ve/veya derecesi belirlenmeye çalış1lır (Karasar, 1999, s.81).

\subsection{Araştırmanın evren ve örneklemi}

Araştırma evrenini İstanbul İlindeki üniversitelerin okul öncesi öğretmenliği programında öğrenim görmekte olan lisans öğrencileri oluşturmaktadır. Araştırma örneklemini ise 20142015 bahar yarıyılında İstanbul Sabahattin Zaim Üniversitesi Eğitim Fakültesi'nde okul öncesi öğretmenliği lisans programında öğrenim görmekte olan ve tesadüfi örnekleme metoduyla seçilen 140 öğrenci oluşturmaktadır.

\subsection{Veri toplama araçları}

Verilerin toplanmasında araştırmacı tarafından geliştirilen Kişisel Bilgi Formu, "Sosyal Beceri Envanteri (SBE)" ve "Problem Çözme Envanteri (SBE)" kullanılmıştır.

Kişisel Bilgi Formu: Bu form, örneklemin demografik özellikleri hakkında bilgi elde etmek amacıyla araştırmacı tarafından geliştirilmiştir. Bu formda okulöncesi öğretmen adaylarına yaş, sınıf, öğrenim görürken kalınan yer, gelir düzeyi ve ailedeki kardeş sayısına ilişkin sorular sorulmuştur.

Problem Çözme Envanteri: Heppner ve Petersen (1982) tarafindan bireylerin problem çözme becerilerini belirlemek amacıyla geliştirilen ölçek; Şahin, Şahin ve Heppner tarafından (1993) tarafından Türkçe formuna uyarlanmıştır. Hiçbir zaman, ender olarak, arada sırada, sık sık, çoğunlukla ve her zaman biçiminde altılı Likert yapısında 35 maddeden oluşmaktadır.1, $2,3,4,11,13,14,15,17,21,25,26,30$ ve 34 numaralı maddeler ters kodlanırken 9,22 ve 29 numaralı maddeler puanlamaya katılmamaktadır. Puanlama yapılırken olumlu ifadelerde " her zaman böyle davranırım" 6, "hiçbir zaman böyle davranmam" 1 puan olarak kodlanmıştır. 
Yaşar Ekici, F. (2017). Examination of preservice preschool teachers' level of problem solving and social skills. International Journal of Social Sciences and Education Research, 3(1), 16-38.

Ölçekten alınan puanların yüksek olması bireyin problem çözme becerileri konusunda kendini yetersiz olarak algıladığını ifade etmektedir (Turan, 2010). Ölçeğin puan aralığı 32192'dir.Ölçek, "aceleci yaklaşım”, “düşünen yaklaşım”, "kaçıngan yaklaşım”, “değerlendirici yaklaşım", "kendine güvenli yaklaşım” ve "planlı yaklaşım” olarak 6 faktörden oluşurken iç tutarlılık güvenirlik katsayısı 0,88 bulunmuştur.

Sosyal Beceri Envanteri: Bu envanter, Riggio (1986) tarafından geliştirilmiştir. Envanter, duyuşsal anlatımcılık (DA), duyuşsal duyarlık (DD), duyuşsal kontrol (DK), sosyal anlatımc1lık (SA), sosyal duyarlık (SD) ve sosyal kontrol (SK) alt boyutları içermektedir. Yüksel (2004), tarafından yapılan güvenilirlik analizi sonucu $\mathrm{r}=.92$ olarak bulunmuştur. Sosyal Beceri Envanteri'nin alt boyutlarının güvenilirlil katsayıları ise; Duyuşsal Anlatımcılık .81, Duyuşsal Duyarlık .87, Duyuşsal Kontrol .80, Sosyal Anlatımcılık .89, Sosyal Duyarlık .88, Sosyal Kontrol .89 şeklinde bulunmuştur. Yüksel (2004) tarafindan yapılan benzer ölçek geçerliği çalışması sonucunda ölçeğin Kendini Ayarlama Ölçeği ile arasında .63 korelasyon bulunmuştur. Envanterin bütününe ilişkin benzer ölçekler geçerlik katsayısı 0.01 düzeyinde anlamlı bulunmuştur. Bu bulgular Sosyal Beceri Envanterinin geçerli olduğunu göstermektedir (Yüksel, 2004). Ölçeğin alt boyutlarının açıklamaları ise şu şekildedir. Duyuşsal anlatımcılık alt boyutu bireyin sözel olmayan iletişim becerilerini ölçmektedir. Duyuşsal duyarlılık alt boyutu başkalarının sözel olmayan mesajlarını alma ve çözümleme becerilerini, duyuşsal kontrol alt boyutu ise bireyin sözel olmayan tepkilerini düzenleme ve kontrol etme becerilerini ölçmektedir. Ölçeğin sosyal anlatımcılık alt boyutu, sözel ifade becerilerini, sosyal duyarlılık alt boyutu sözel mesajları çözümleme becerilerini ve sosyal kontrol alt boyutu ise sosyal rol oynama becerilerini ölçmektedir (Yüksel,2004).

\subsection{Verilerin toplanmast}

Araştırmaya ilişkin veriler 2014-2015 bahar yarıyılında ders saatleri içinde derse giren öğretim elemanlarının yardımı ile toplanmıştır. Kararlaştııılan saatlerde "Kişisel Bilgi Formu" ve "Sosyal Beceri Envanteri" ve "Problem Çözme Envanteri”" birlikte uygulanmıştır. Veri toplama araçları, uygulamanın yapıldığı gün sınıfta bulunan öğrenciler tarafından cevaplanmış, uygulama için öğrencilere gerekli süre tanınmıştır.

\subsection{Verilerin çözümlenmesi}

Araştırma için toplanan veriler SPSS 20 programı kullanılarak analiz edilmiştir. Verilerin analizinde; Frekans-\% dağılımları, Kruskal Wallis H Testi, Bağımsız Grup t Testi, Mann Whitney U Testi kullanılmıştır.

\section{Bulgular}

Araştırmadan elde edilen bulgular alt amaçlar çerçevesinde tablolar halinde aşağıda sunulmuştur.

\subsection{Birinci alt amaca ilişkin bulgular}

Araştırmanın birinci alt amacı okul öncesi öğretmen adaylarının problem çözme ve sosyal beceri düzeylerinin yaş, sınıf, öğrenim görürken kalınan yer, gelir düzeyi ve ailedeki kardeş sayısına göre farklılaşıp farklılaşmadığını belirlemeye yöneliktir. Aşağıda, birinci alt amaca ilişkin bulgular tablolar halinde sunulmuştur. 
Yaşar Ekici, F. (2017). Okul öncesi öğretmen adaylarının problem çözme ve sosyal beceri düzeylerinin incelenmesi. International Journal of Social Sciences and Education Research, 3(1), 16-38.

Tablo 1. Katılımcıların Problem Çözme Envanteri'nden aldıkları puanların yaşa göre farklılaşıp farklılaşmadığını belirlemek üzere yapılan Kruskal Wallis-H test sonuçları

\begin{tabular}{|c|c|c|c|c|c|c|}
\hline Ölçekler & Yaş aralığı & $\mathbf{N}$ & Sira Ort. & SD & $\overline{X^{2}}$ & $\mathbf{P}$ \\
\hline $\begin{array}{l}\text { PROBLEM } \\
\text { ÇÖZME EN- } \\
\text { VANTERİ } \\
\text { GENELİ }\end{array}$ & $\begin{array}{c}18-20 \\
21-23 \\
24-26 \\
27-29 \\
30-32 \\
33-35 \\
\text { Toplam }\end{array}$ & $\begin{array}{r}43 \\
69 \\
5 \\
7 \\
2 \\
2 \\
128\end{array}$ & $\begin{array}{r}59,00 \\
65,72 \\
60,30 \\
75,64 \\
67,75 \\
108,75\end{array}$ & 5 & 4,581 & , 469 \\
\hline $\begin{array}{l}\text { PÇE-Aceleci } \\
\text { Yaklaşım Alt } \\
\text { Boyutu }\end{array}$ & $\begin{array}{r}18-20 \\
21-23 \\
24-26 \\
27-29 \\
30-32 \\
33-35 \\
\text { Toplam } \\
\end{array}$ & $\begin{array}{r}43 \\
69 \\
5 \\
7 \\
2 \\
2 \\
128 \\
\end{array}$ & $\begin{array}{r}59,20 \\
67,69 \\
57,80 \\
75,93 \\
7,00 \\
102,75\end{array}$ & 5 & 9,205 &, 101 \\
\hline $\begin{array}{l}\text { PÇE-Düşünen } \\
\text { Yaklaşım Alt } \\
\text { Boyutu }\end{array}$ & $\begin{array}{r}18-20 \\
21-23 \\
24-26 \\
27-29 \\
30-32 \\
33-35 \\
\text { Toplam } \\
\end{array}$ & $\begin{array}{r}43 \\
69 \\
5 \\
7 \\
2 \\
2 \\
128\end{array}$ & $\begin{array}{l}62,17 \\
63,46 \\
57,30 \\
80,21 \\
84,25 \\
93,75\end{array}$ & 5 & 3,491 & ,625 \\
\hline $\begin{array}{l}\text { PÇE-Kaçın- } \\
\text { gan Yaklaşım } \\
\text { Alt Boyutu }\end{array}$ & $\begin{array}{r}18-20 \\
21-23 \\
24-26 \\
27-29 \\
30-32 \\
33-35 \\
\text { Toplam }\end{array}$ & $\begin{array}{r}43 \\
69 \\
5 \\
7 \\
2 \\
2 \\
128\end{array}$ & $\begin{array}{l}54,21 \\
69,36 \\
63,30 \\
68,79 \\
73,25 \\
97,50\end{array}$ & 5 & 6,348 &, 274 \\
\hline $\begin{array}{l}\text { PÇE-Değer- } \\
\text { lendirici } \\
\text { Yaklaşım Alt } \\
\text { Boyutu }\end{array}$ & $\begin{array}{r}18-20 \\
21-23 \\
24-26 \\
27-29 \\
30-32 \\
33-35 \\
\text { Toplam }\end{array}$ & $\begin{array}{r}43 \\
69 \\
5 \\
7 \\
2 \\
2 \\
128\end{array}$ & $\begin{array}{l}62,35 \\
65,83 \\
32,70 \\
75,29 \\
94,50 \\
76,75\end{array}$ & 5 & 6,097 & ,297 \\
\hline $\begin{array}{l}\text { PÇE-Kendine } \\
\text { Güvenli } \\
\text { Yaklaşım Alt } \\
\text { Boyutu }\end{array}$ & $\begin{array}{r}18-20 \\
21-23 \\
24-26 \\
27-29 \\
30-32 \\
33-35 \\
\text { Toplam }\end{array}$ & $\begin{array}{r}43 \\
69 \\
5 \\
7 \\
2 \\
2 \\
128\end{array}$ & $\begin{array}{r}63,10 \\
61,66 \\
71,30 \\
76,07 \\
94,75 \\
104,75\end{array}$ & 5 & 5,017 & ,414 \\
\hline $\begin{array}{l}\text { PÇE-Planlı } \\
\text { Yaklaşım Alt } \\
\text { Boyutu }\end{array}$ & $\begin{array}{r}18-20 \\
21-23 \\
24-26 \\
27-29 \\
30-32 \\
33-35 \\
\text { Toplam }\end{array}$ & $\begin{array}{r}43 \\
69 \\
5 \\
7 \\
2 \\
2 \\
128\end{array}$ & $\begin{array}{r}63,00 \\
64,25 \\
63,10 \\
62,29 \\
103,25 \\
78,00\end{array}$ & 5 & 2,575 & ,765 \\
\hline
\end{tabular}

Tablo 1 incelendiğinde; okul öncesi öğretmen adaylarının yaşa göre Problem Çözme Envanteri genelinden $\left(X^{2}=4,581 ; p>.05\right)$, Aceleci Yaklaşım $\left(X^{2}=9,205, ; p>.05\right)$, Düşünen Yaklaşım $\left(X^{2}=3,491 ; p>.05\right)$, Kaçıngan Yaklaşım $\left(X^{2}=6,348 ; p>.05\right)$, Değerlendirici Yaklaşım $\left(\mathrm{X}^{2}=6,097 ; \mathrm{p}>.05\right)$, Kendine Güvenli Yaklaşım $\left(\mathrm{X}^{2}=5,017 ; \mathrm{p}>.05\right)$, Planlı Yaklaşım $\left(\mathrm{X}^{2}=2,575 ; \mathrm{p}>.05\right)$ alt boyutlarından aldıkları puanlar arasındaki farkın istatistiksel olarak anlamlı bulunmadığı görülmektedir. 
Yaşar Ekici, F. (2017). Examination of preservice preschool teachers' level of problem solving and social skills. International Journal of Social Sciences and Education Research, 3(1), 16-38.

Tablo 2.Katılımcıların Sosyal Beceri Envanteri'nden aldıkları puanların yaşa göre farklılaşıp farklılaşmadığını belirlemek üzere yapılan Kruskal Wallis-H test sonuçları

\begin{tabular}{|c|c|c|c|c|c|c|}
\hline Ölçekler & Yaş aralığı & $\mathbf{N}$ & Sira Ort. & SD & $\overline{X^{2}}$ & $\overline{\mathbf{P}}$ \\
\hline & $18-20$ & 43 & 76,83 & & & \\
\hline SOSYAL BE- & $21-23$ & 69 & 65,43 & & & \\
\hline CERİ EN- & $24-26$ & 5 & 48,29 & 5 & 7,329 & 197 \\
\hline VANTERİ & $27-29$ & 7 & 74,14 & & & \\
\hline \multirow[t]{3}{*}{ GENELI } & $30-32$ & 2 & 39,25 & & & \\
\hline & $33-35$ & 2 & 32,50 & & & \\
\hline & Toplam & 128 & & & & \\
\hline SBE-Duyuşsal & $18-20$ & 43 & 71,89 & & & \\
\hline Anlatımcılık & $21-23$ & 69 & 67,11 & & & \\
\hline \multirow[t]{5}{*}{ Alt Boyutu } & $24-26$ & 5 & 33,08 & 5 & 6,425 & ,267 \\
\hline & $27-29$ & 7 & 62,29 & & & \\
\hline & $30-32$ & 2 & 87,75 & & & \\
\hline & $33-35$ & 2 & 50,75 & & & \\
\hline & Toplam & 128 & & & & \\
\hline SBE-Duyuşsal & $18-20$ & 43 & 72,60 & & & \\
\hline Duyarlılık Alt & $21-23$ & 69 & 64,01 & & & \\
\hline \multirow{5}{*}{ Boyutu } & $24-26$ & 5 & 65,17 & 5 & 4,573 & ,470 \\
\hline & $27-29$ & 7 & 59,29 & & & \\
\hline & $30-32$ & 2 & 105,50 & & & \\
\hline & $33-35$ & 2 & 41,25 & & & \\
\hline & Toplam & 128 & & & & \\
\hline SBE-Duyuşsal & $18-20$ & 43 & 75,40 & & & \\
\hline Kontrol Alt & $21-23$ & 69 & 60,30 & & & \\
\hline \multirow[t]{5}{*}{ Boyutu } & $24-26$ & 5 & 92,50 & 5 & 7,668 & ,175 \\
\hline & $27-29$ & 7 & 66,21 & & & \\
\hline & $30-32$ & 2 & 65,25 & & & \\
\hline & $33-35$ & 2 & 43,75 & & & \\
\hline & Toplam & 128 & & & & \\
\hline SBE-Sosyal & $18-20$ & 43 & 75,22 & & & \\
\hline Anlatımcılık & $21-23$ & 69 & 62,44 & & & \\
\hline \multirow[t]{5}{*}{ Alt Boyutu } & $24-26$ & 5 & 71,25 & 5 & 6,388 & 270 \\
\hline & $27-29$ & 7 & 75,57 & & & \\
\hline & $30-32$ & 2 & 33,50 & & & \\
\hline & $33-35$ & 2 & 34,75 & & & \\
\hline & Toplam & 128 & & & & \\
\hline SBE-Sosyal & $18-20$ & 43 & 76,60 & & & \\
\hline Duyarlılık Alt & $21-23$ & 69 & 63,06 & & & \\
\hline \multirow[t]{5}{*}{ Boyutu } & $24-26$ & 5 & 51,67 & 5 & 6,711 & ,243 \\
\hline & $27-29$ & 7 & 73,93 & & & \\
\hline & $30-32$ & 2 & 40,00 & & & \\
\hline & $33-35$ & 2 & 39,75 & & & \\
\hline & Toplam & 128 & & & & \\
\hline SBE-Sosyal & $18-20$ & 43 & 78,59 & & & \\
\hline Kontrol Alt & $21-23$ & 69 & 63,58 & & & \\
\hline \multirow{5}{*}{ Boyutu } & $24-26$ & 5 & 36,75 & 5 & 12,480 & ,029* \\
\hline & $27-29$ & 7 & 73,86 & & & \\
\hline & $30-32$ & 2 & 42,50 & & & \\
\hline & $33-35$ & 2 & 19,00 & & & \\
\hline & Toplam & 128 & & & & \\
\hline
\end{tabular}

Tablo2 incelendiğinde; okul öncesi öğretmen adaylarının yaşa göre Sosyal Beceri Envanteri genelinden $\left(X^{2}=7,329 ; p>.05\right)$, Duyuşsal Anlatımcilık $\left(X^{2}=6,425 ; p>.05\right)$, Duyuşsal Duyarlık $\left(X^{2}=4,573 ; p>.05\right)$, Duyuşsal Kontrol $\left(X^{2}=7,668 ; p>.05\right)$, Sosyal Anlatımcılık $\left(X^{2}=6,388 ; \mathrm{p}>.05\right)$ ve Sosyal Duyarlık $\left(\mathrm{X}^{2}=6,711 ; \mathrm{p}>.05\right)$ alt boyutlarından aldıkları puanlar arasındaki farkın istatistiksel olarak anlamlı bulunmadığ görülmektedir. 
Yaşar Ekici, F. (2017). Okul öncesi öğretmen adaylarının problem çözme ve sosyal beceri düzeylerinin incelenmesi. International Journal of Social Sciences and Education Research, 3(1), 16-38.

Okul öncesi öğretmen adaylarının yaşa göre Sosyal Beceri Envanteri’nin Sosyal Kontrol alt boyutundan aldıkları puanlar arasındaki farkın istatistiksel olarak anlamlı olduğu görülmektedir $\left(\mathrm{X}^{2}=12,480 ; \mathrm{p}<.05\right)$. Bu işlemin ardından belirlenen anlamlı farklılığın hangi gruplardan kaynaklandığını belirlemek üzere tamamlayıcı karşılaştırma tekniklerine geçilmiştir. Bu amaçla kullanılan özel bir test tekniği bulunmadığından ikili karşılaştırmalarda tercih edilen Bağımsız Grup t Testi ve Mann Whitney-U Testleri uygulanmış ve gruplar arasında tek tek karşılaştırmaya gidilmiştir. Elde edilen bulgular, aşağıda tablolar halinde sunulmuştur.

Tablo 3. Okul öncesi öğretmen adaylarının Sosyal Kontrol Alt Boyutundan aldıkları puanların yaşa göre hangi gruplar arasında farklılaşıp farklılaşmadığını belirlemek üzere yapılan Mann Withney U Testi sonuçları

\begin{tabular}{llcccccc}
\hline Alt Boyut & Yaş & N & Sıra Ort. & Sıra Topl. & Z & U & P \\
\hline SBE-Sosyal & $18-20$ & 45 & 27,74 & 1248,50 & $-2,302$ & 56,500 &, $021^{*}$ \\
Kontrol Alt & $24-26$ & 6 & 12,92 & 77,50 & & & \\
Boyutu & Toplam & 51 & & & & & \\
& & & & & & & \\
\hline SBE-Sosyal & $18-20$ & 45 & 24,83 & 1117,50 & $-1,983$ & 7,500 & \\
Kontrol Alt & $33-35$ & 2 & 5,25 & 10,50 & & & \\
Boyutu & Toplam & 47 & & & & & \\
\hline SBE-Sosyal & $24-26$ & 6 & 4,67 & 28,00 & $-2,003$ & 7,000 &, $045^{*}$ \\
Kontrol Alt & $27-29$ & 7 & 9,00 & 63,00 & & & \\
Boyutu & Toplam & 13 & & & & & \\
\hline
\end{tabular}

Tablo 3 incelendiğinde görülmektedir ki okul öncesi öğretmen adaylarının Sosyal Kontrol alt boyutundan aldıkları puanlarda gruplar arasındaki fark anlamlı bulunmuştur $(\mathrm{p}<, 05)$. Buna göre sıra ortalamalarına bakıldığında; $18-20$ yaş arasındaki katılımcıların (sıra ort. $=1248,50$ ) 24-26 yaş arası katılımcılara (sıra ort. $=77,50$ ) oranla Sosyal Kontrol alt boyutundan daha yüksek puan aldıkları görülmektedir. 18-20 yaş arasındaki katılımcıların (sıra ort. $=24,83$ ) 33-35 yaş arası katılımcılara (sıra ort. $=5,25$ ) oranla Sosyal Kontrol alt boyutundan daha yüksek puan aldıkları görülmektedir. 18-20 yaş arasındaki katılımcıların (sıra ort.=1248,50) 24-26 yaş arası katılımcılara (sıra ort. $=77,50$ ) oranla Sosyal Kontrol alt boyutundan daha yüksek puan aldıkları görülmektedir. 24-26 yaş arasındaki katılımcıların (sıra ort.=4,67) 27-29 yaş arası katılımcilara (sıra ort. $=9,00$ ) oranla Sosyal Kontrol alt boyutundan daha yüksek puan aldıkları görülmektedir.

Tablo 4. Okul öncesi öğretmen adaylarının sosyal kontrol alt boyutundan aldıkları puanların yaşa göre hangi gruplar arasında farklılaşıp farklılaşmadığını belirlemek üzere yapılan Bağımsız Grup T Testi sonuçları

\begin{tabular}{|c|c|c|c|c|c|c|c|c|}
\hline \multirow[t]{2}{*}{ Alt boyut } & \multirow[t]{2}{*}{ Yaş } & \multirow[t]{2}{*}{$\mathbf{N}$} & \multirow[t]{2}{*}{$\overline{\mathbf{X}}$} & \multirow[t]{2}{*}{ SS } & \multirow[t]{2}{*}{$\mathbf{S h}_{\overline{\mathbf{x}}}$} & \multicolumn{3}{|c|}{ T Testi } \\
\hline & & & & & & $\mathbf{t}$ & Sd & $\mathbf{P}$ \\
\hline $\begin{array}{l}\text { Sosyal } \\
\text { Kontrol }\end{array}$ & $\begin{array}{l}18-20 \\
21-23\end{array}$ & $\begin{array}{l}45 \\
71\end{array}$ & $\begin{array}{l}43,53 \\
39,69\end{array}$ & $\begin{array}{r}11,034 \\
9,486\end{array}$ & $\begin{array}{l}1,645 \\
1,126\end{array}$ & 1,995 & 114 & ,048* \\
\hline
\end{tabular}

Tablo 4 incelendiğinde Sosyal Kontrol alt boyutunda grupların aritmetik ortalamaları arasindaki fark istatistiksel olarak anlamlı bulunmuştur $(\mathrm{t}=1,995 ; \mathrm{p}<.05)$. Farkın hangi grup lehine olduğunu tespit etmek amacıyla ortalamalar incelendiğinde, 18-20 arasındaki katılımcıların aritmetik ortalamasının $(\overline{\mathrm{X}}=43,53), 21-23$ yaş arasındaki katılımcıların aritmetik ortalamasın- 
Yaşar Ekici, F. (2017). Examination of preservice preschool teachers' level of problem solving and social skills. International Journal of Social Sciences and Education Research, 3(1), 16-38.

dan $(\bar{X}=39,69)$ daha yüksek olduğu görülmektedir. Yani, söz konusu farkl111k 18-20 yar arasındaki okul öncesi öğretmen adayları lehine gerçekleşmiştir.

Tablo 5. Katılımcıların Problem Çözme Envanteri'nden aldıkları puanların sınıf değişkenine göre farklılaşıp farklılaşmadığını belirlemek üzere yapılan Kruskal Wallis-H test sonuçlar1

\begin{tabular}{|c|c|c|c|c|c|c|}
\hline Ölçekler & Sinıf & $\mathbf{N}$ & Sira Ort. & SD & $\mathrm{X}^{2}$ & $\mathbf{P}$ \\
\hline $\begin{array}{l}\text { PROBLEM } \\
\text { ÇÖZME EN- } \\
\text { VANTERİ } \\
\text { GENELI }\end{array}$ & $\begin{array}{r}\text { 1.sinif } \\
\text { 2.sinif } \\
\text { 3.sinif } \\
\text { 4.sinif } \\
\text { Toplam }\end{array}$ & $\begin{array}{r}31 \\
29 \\
54 \\
17 \\
131 \\
\end{array}$ & $\begin{array}{l}31,00 \\
29,00 \\
54,00 \\
17,00\end{array}$ & 3 & 5,376 & , 146 \\
\hline $\begin{array}{l}\text { PÇE-Aceleci } \\
\text { Yaklaşım Alt } \\
\text { Boyutu }\end{array}$ & $\begin{array}{r}\text { 1.sinif } \\
\text { 2.sinif } \\
\text { 3.sinif } \\
\text { 4.sinif } \\
\text { Toplam }\end{array}$ & $\begin{array}{r}31 \\
29 \\
54 \\
17 \\
131\end{array}$ & $\begin{array}{l}71,03 \\
72,02 \\
63,06 \\
55,88\end{array}$ & 3 & 2,822 & , 420 \\
\hline $\begin{array}{l}\text { PÇE-Düşünen } \\
\text { Yaklaşım Alt } \\
\text { Boyutu }\end{array}$ & $\begin{array}{r}\text { 1.sinif } \\
\text { 2.sinif } \\
\text { 3.sinif } \\
\text { 4.sinif } \\
\text { Toplam }\end{array}$ & $\begin{array}{r}31 \\
29 \\
54 \\
17 \\
131\end{array}$ & $\begin{array}{l}62,19 \\
70,10 \\
64,07 \\
72,06\end{array}$ & 3 & 1,227 & ,746 \\
\hline $\begin{array}{l}\text { PÇE-Kaçın- } \\
\text { gan Yaklaşım } \\
\text { Alt Boyutu }\end{array}$ & $\begin{array}{r}\text { 1.sinif } \\
\text { 2.sinif } \\
\text { 3.sinif } \\
\text { 4.sinif } \\
\text { Toplam }\end{array}$ & $\begin{array}{r}31 \\
29 \\
54 \\
17 \\
131 \\
\end{array}$ & $\begin{array}{l}69,16 \\
66,78 \\
62,13 \\
71,21\end{array}$ & 3 & 1,119 & ,772 \\
\hline $\begin{array}{l}\text { PÇE-Değer- } \\
\text { lendirici } \\
\text { Yaklaşım Alt } \\
\text { Boyutu }\end{array}$ & $\begin{array}{r}\text { 1.sinif } \\
2 . \text { sinif } \\
3 . \text { sinif } \\
4 . \text { sinif } \\
\text { Toplam } \\
\end{array}$ & $\begin{array}{r}31 \\
29 \\
54 \\
17 \\
131 \\
\end{array}$ & $\begin{array}{l}64,85 \\
76,26 \\
60,90 \\
66,79\end{array}$ & 3 & 3,165 & ,367 \\
\hline $\begin{array}{l}\text { PÇE-Kendine } \\
\text { Güvenli } \\
\text { Yaklaşım Alt } \\
\text { Boyutu }\end{array}$ & $\begin{array}{r}\text { 1.sinif } \\
2 . \text { sinif } \\
3 . \text { sinif } \\
4 . \text { sinif } \\
\text { Toplam }\end{array}$ & $\begin{array}{r}31 \\
29 \\
54 \\
17 \\
131\end{array}$ & $\begin{array}{l}70,11 \\
74,95 \\
59,33 \\
64,41\end{array}$ & 3 & 3,683 & ,298 \\
\hline $\begin{array}{l}\text { PÇE-Planlı } \\
\text { Yaklaşım Alt } \\
\text { Boyutu }\end{array}$ & $\begin{array}{r}\text { 1.sinif } \\
\text { 2.sinif } \\
\text { 3.sinif } \\
\text { 4.sinif } \\
\text { Toplam }\end{array}$ & $\begin{array}{r}31 \\
29 \\
54 \\
17 \\
131\end{array}$ & $\begin{array}{l}60,79 \\
80,40 \\
61,36 \\
65,68\end{array}$ & 3 & 5,612 & ,132 \\
\hline
\end{tabular}

Tablo 5 incelendiğinde; okul öncesi öğretmen adaylarının sınıfa göre Problem Çözme Envanteri genelinden $\left(X^{2}=5,376 ; p>.05\right)$, Aceleci Yaklaşım $\left(X^{2}=2,822, ; p>.05\right)$, Düşünen Yaklaşım $\left(X^{2}=1,227 ; p>.05\right)$, Kaçıngan Yaklaşım $\left(X^{2}=1,119 ; p>.05\right)$, Değerlendirici Yaklaşım $\left(\mathrm{X}^{2}=3,165 ; \mathrm{p}>.05\right)$, Kendine Güvenli Yaklaşım $\left(\mathrm{X}^{2}=3,683 ; \mathrm{p}>.05\right)$, Planlı Yaklaşım $\left(\mathrm{X}^{2}=5,612 ; \mathrm{p}>.05\right)$ alt boyutlarından aldıkları puanlar arasındaki farkın istatistiksel olarak anlamlı bulunmadığı görülmektedir. 
Yaşar Ekici, F. (2017). Okul öncesi öğretmen adaylarının problem çözme ve sosyal beceri düzeylerinin incelenmesi. International Journal of Social Sciences and Education Research, 3(1), 16-38.

Tablo 6. Katılımcıların Sosyal Beceri Envanteri'nden aldıkları puanların yaşa göre farkl1laşıp farklılaşmadığını belirlemek üzere yapılan Kruskal Wallis-H Test sonuçları

\begin{tabular}{|c|c|c|c|c|c|c|}
\hline Ölçekler & Yaş & $\mathbf{N}$ & Sira Ort. & SD & $\mathbf{X}^{2}$ & $\mathbf{P}$ \\
\hline $\begin{array}{l}\text { SOSYAL BE- } \\
\text { CERİ EN- } \\
\text { VANTERİ } \\
\text { GENELİ }\end{array}$ & $\begin{array}{c}\text { 1.sinif } \\
2 . \text { sinif } \\
\text { 3.sinif } \\
\text { 4.sinif } \\
\text { Toplam }\end{array}$ & $\begin{array}{r}30 \\
29 \\
56 \\
23 \\
138 \\
\end{array}$ & $\begin{array}{l}67,85 \\
68,93 \\
73,97 \\
61,48\end{array}$ & 3 & 1,684 & ,640 \\
\hline $\begin{array}{l}\text { SBE-Duyuşsal } \\
\text { Anlatımcılık } \\
\text { Alt Boyutu }\end{array}$ & $\begin{array}{c}\text { 1.sinif } \\
\text { 2.sinif } \\
\text { 3.sinıf } \\
\text { 4.sinif } \\
\text { Toplam }\end{array}$ & $\begin{array}{r}30 \\
29 \\
56 \\
23 \\
138\end{array}$ & $\begin{array}{l}68,23 \\
70,57 \\
70,85 \\
60,72\end{array}$ & 3 & 1,173 & ,759 \\
\hline $\begin{array}{l}\text { SBE-Duyuşsal } \\
\text { Duyarlılık Alt } \\
\text { Boyutu }\end{array}$ & $\begin{array}{l}\text { 1.sinif } \\
\text { 2.sinif } \\
\text { 3.sinif } \\
\text { 4.sinif } \\
\text { Toplam }\end{array}$ & $\begin{array}{r}30 \\
29 \\
56 \\
23 \\
138\end{array}$ & $\begin{array}{l}66,27 \\
70,36 \\
72,30 \\
60,07\end{array}$ & 3 & 1,728 & ,631 \\
\hline $\begin{array}{l}\text { SBE-Duyuşsal } \\
\text { Kontrol Alt } \\
\text { Boyutu }\end{array}$ & $\begin{array}{c}\text { 1.sinif } \\
\text { 2.sinif } \\
\text { 3.sinıf } \\
\text { 4.sinıf } \\
\text { Toplam }\end{array}$ & $\begin{array}{r}30 \\
29 \\
56 \\
23 \\
138 \\
\end{array}$ & $\begin{array}{l}62,30 \\
71,64 \\
68,28 \\
73,28\end{array}$ & 3 & 1,265 & ,737 \\
\hline $\begin{array}{l}\text { SBE-Sosyal } \\
\text { Anlatımcılık } \\
\text { Alt Boyutu }\end{array}$ & $\begin{array}{c}\text { 1.sinıf } \\
\text { 2.sinıf } \\
\text { 3.sinıf } \\
\text { 4.sinıf } \\
\text { Toplam }\end{array}$ & $\begin{array}{r}30 \\
29 \\
56 \\
23 \\
138\end{array}$ & $\begin{array}{l}59,18 \\
59,41 \\
80,24 \\
63,65\end{array}$ & 3 & 8,411 & ,038* \\
\hline $\begin{array}{l}\text { SBE-Sosyal } \\
\text { Duyarlılık Alt } \\
\text { Boyutu }\end{array}$ & $\begin{array}{l}\text { 1.sinif } \\
\text { 2.sınıf } \\
\text { 3.sinif } \\
\text { 4.sinif } \\
\text { Toplam }\end{array}$ & $\begin{array}{r}30 \\
29 \\
56 \\
23 \\
138\end{array}$ & $\begin{array}{l}62,17 \\
70,79 \\
75,44 \\
57,39\end{array}$ & 3 & 4,413 & ,220 \\
\hline $\begin{array}{l}\text { SBE-Sosyal } \\
\text { Kontrol Alt } \\
\text { Boyutu }\end{array}$ & $\begin{array}{l}\text { 1.sinif } \\
\text { 2.sinif } \\
\text { 3.sinif } \\
\text { 4.sinif } \\
\text { Toplam }\end{array}$ & $\begin{array}{r}30 \\
29 \\
56 \\
23 \\
138\end{array}$ & $\begin{array}{l}67,12 \\
66,46 \\
74,53 \\
58,37\end{array}$ & 3 & 2,924 & ,404 \\
\hline
\end{tabular}

Tablo 6 incelendiğinde; okul öncesi öğretmen adaylarının sınıf değişkenine göre Sosyal Beceri Envanteri genelinden $\left(X^{2}=1,684 ; p>.05\right)$, Duyuşsal Anlatımcılık $\left(X^{2}=1,173, ; p>.05\right)$, Duyuşsal Duyarlık $\left(X^{2}=1,728 ; p>.05\right)$, Duyuşsal Kontrol $\left(X^{2}=1,265 ; p>.05\right)$, Sosyal Duyarlık $\left(X^{2}=4,413 ; p>.05\right)$ ve Sosyal Kontrol $\left(X^{2}=2,924 ; p>.05\right)$ alt boyutlarından aldıkları puanlar arasındaki farkın istatistiksel olarak anlamlı bulunmadığı görülmektedir.

Okul öncesi öğretmen adaylarının sınıf değişkenine göre Sosyal Beceri Envanteri'nin Sosyal Anlatımcılık alt boyutundan aldıkları puanlar arasındaki farkın istatistiksel olarak anlamlı olduğu görülmektedir $\left(\mathrm{X}^{2}=8,411 ; \mathrm{p}<.05\right)$. Bu işlemin ardından belirlenen anlamlı farklılığın hangi gruplardan kaynaklandığını belirlemek üzere tamamlayıcı karşılaştırma tekniklerine geçilmiştir. Bu amaçla kullanılan özel bir test tekniği bulunmadığından ikili karşılaştırmalarda tercih edilen Bağımsız Grup t Testi ve Mann Whitney-U Testleri uygulanmış ve gruplar arasında tek tek karşılaştırmaya gidilmiştir. Elde edilen bulgular, aşağıda tablolar halinde sunulmuştur. 
Yaşar Ekici, F. (2017). Examination of preservice preschool teachers' level of problem solving and social skills. International Journal of Social Sciences and Education Research, 3(1), 16-38.

Tablo 7. Okul öncesi öğretmen adaylarının sosyal anlatımcılık alt boyutundan aldıkları puanların sınıf değişkenine göre hangi gruplar arasında farklılaşıp farklılaşmadığını belirlemek üzere yapılan Mann Withney U Testi sonuçları

\begin{tabular}{llcccccc}
\hline Alt Boyut & Sinıf & N & Sira Ort. & Sira Topl. & Z & U & P \\
\hline SBE-Sosyal & 2.sinıf & 28 & 33,38 & 934,50 & $-2,329$ & 528,500 &, $020^{*}$ \\
Anlatımcilık & 3.sinıf & 55 & 46,39 & 2551,50 & & & \\
Alt Boyutu & Toplam & 83 & & & & &
\end{tabular}

Tablo 7 incelendiğinde görülmektedir ki okul öncesi öğretmen adaylarının Sosyal Anlatımcılık alt boyutundan aldıkları puanlarda gruplar arasındaki fark anlamlı bulunmuştur $(\mathrm{p}<, 05)$. Buna göre sıra ortalamalarına bakıldığında; 3.sınıftaki katılımcıların (sıra ort. $=46,39)$ 2. sinıftaki katılımcılara (sıra ort. $=33,38$ ) oranla Sosyal Anlatımcılık alt boyutundan daha yüksek puan aldıkları görülmektedir.

Tablo 8. Okul öncesi öğretmen adaylarının sosyal anlatımcılık alt boyutundan aldıkları puanların sınıf değişkenine göre hangi gruplar arasında farklılaşıp farklılaşmadığını belirlemek üzere yapılan Bağımsız Grup T Testi sonuçları

\begin{tabular}{|c|c|c|c|c|c|c|c|c|}
\hline \multirow[t]{2}{*}{ Alt boyut } & \multirow[t]{2}{*}{ Sinıf } & \multirow[t]{2}{*}{$\mathbf{N}$} & \multirow[t]{2}{*}{$\overline{\mathbf{X}}$} & \multirow[t]{2}{*}{ SS } & \multirow[t]{2}{*}{$\mathbf{S h}_{\overline{\mathbf{x}}}$} & \multicolumn{3}{|c|}{ T Testi } \\
\hline & & & & & & 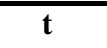 & Sd & $\overline{\mathbf{P}}$ \\
\hline $\begin{array}{l}\text { Sosyal } \\
\text { Kontrol }\end{array}$ & $\begin{array}{l}\text { 1.sinif } \\
3 . \sin 1 f\end{array}$ & $\begin{array}{l}30 \\
55\end{array}$ & $\begin{array}{l}39,10 \\
43,47\end{array}$ & $\begin{array}{l}8,006 \\
8,326\end{array}$ & $\begin{array}{l}1,462 \\
1,123\end{array}$ & $-2,373$ & 61,768 &, $021 *$ \\
\hline
\end{tabular}

Tablo 8 incelendiğinde Sosyal anlatımcılık alt boyutunda grupların aritmetik ortalamaları arasındaki fark istatistiksel olarak anlamlı bulunmuştur $(\mathrm{t}=-2,373 ; \mathrm{p}<.05)$. Farkın hangi grup lehine olduğunu tespit etmek amacıyla ortalamalar incelendiğinde, 3.sınıftaki katılımcıların aritmetik ortalamasının $(\overline{\mathrm{X}}=43,47)$, 1.sınıftaki katılımciların aritmetik ortalamasından $(\bar{X}=39,10)$ daha yüksek olduğu görülmektedir. Yani, söz konusu farklılık 3.sınıftaki okul öncesi öğretmen adayları lehine gerçekleşmiştir. 
Yaşar Ekici, F. (2017). Okul öncesi öğretmen adaylarının problem çözme ve sosyal beceri düzeylerinin incelenmesi. International Journal of Social Sciences and Education Research, 3(1), 16-38.

Tablo 9. Katılımcıların Problem Çözme Envanteri’nden aldıkları puanların öğrenim görürken kalınan yer değişkenine göre farklılaşıp farklılaşmadığını belirlemek üzere yapılan Kruskal Wallis-H Test sonuçları

\begin{tabular}{|c|c|c|c|c|c|c|}
\hline Ölçekler & Sinıf & $\mathbf{N}$ & Sira Ort. & SD & $\mathrm{X}^{2}$ & $\mathbf{P}$ \\
\hline $\begin{array}{l}\text { PROBLEM } \\
\text { ÇÖZME EN- } \\
\text { VANTERİ } \\
\text { GENELI }\end{array}$ & $\begin{array}{r}\text { Aile ile beraber } \\
\text { Ögrrenci evi } \\
\text { Devlet yurdu } \\
\text { Özel yurt } \\
\text { Toplam } \\
\end{array}$ & $\begin{array}{r}99 \\
8 \\
2 \\
20 \\
129 \\
\end{array}$ & $\begin{array}{l}64,86 \\
57,50 \\
75,50 \\
67,63\end{array}$ & 3 & ,580 & ,901 \\
\hline $\begin{array}{l}\text { PÇE-Aceleci } \\
\text { Yaklaşım Alt } \\
\text { Boyutu }\end{array}$ & $\begin{array}{r}\text { Aile ile beraber } \\
\text { Öğrenci evi } \\
\text { Devlet yurdu } \\
\text { Özel yurt } \\
\text { Toplam }\end{array}$ & $\begin{array}{r}99 \\
8 \\
2 \\
20 \\
129\end{array}$ & $\begin{array}{l}66,76 \\
50,75 \\
96,75 \\
58,80\end{array}$ & 3 & 3,396 & ,334 \\
\hline $\begin{array}{l}\text { PÇE-Düşünen } \\
\text { Yaklaşım Alt } \\
\text { Boyutu }\end{array}$ & $\begin{array}{r}\text { Aile ile beraber } \\
\text { Öğrenci evi } \\
\text { Devlet yurdu } \\
\text { Özel yurt } \\
\text { Toplam }\end{array}$ & $\begin{array}{r}99 \\
8 \\
2 \\
20 \\
129\end{array}$ & $\begin{array}{l}64,33 \\
60,13 \\
75,50 \\
69,20\end{array}$ & 3 &, 580 & ,901 \\
\hline $\begin{array}{l}\text { PÇE-Kaçın- } \\
\text { gan Yaklaşım } \\
\text { Alt Boyutu }\end{array}$ & $\begin{array}{r}\text { Aile ile beraber } \\
\text { Ögrrenci evi } \\
\text { Devlet yurdu } \\
\text { Özel yurt } \\
\text { Toplam }\end{array}$ & $\begin{array}{r}99 \\
8 \\
2 \\
20 \\
129\end{array}$ & $\begin{array}{l}68,36 \\
59,94 \\
44,50 \\
52,43\end{array}$ & 3 & 3,849 & ,278 \\
\hline $\begin{array}{l}\text { PÇE-Değer- } \\
\text { lendirici } \\
\text { Yaklaşım Alt } \\
\text { Boyutu }\end{array}$ & $\begin{array}{r}\text { Aile ile beraber } \\
\text { Öğrenci evi } \\
\text { Devlet yurdu } \\
\text { Özel yurt } \\
\text { Toplam } \\
\end{array}$ & $\begin{array}{r}99 \\
8 \\
2 \\
20 \\
129 \\
\end{array}$ & $\begin{array}{l}68,36 \\
59,94 \\
44,50 \\
52,43\end{array}$ & 3 & 1,279 & ,734 \\
\hline $\begin{array}{l}\text { PÇE-Kendine } \\
\text { Güvenli } \\
\text { Yaklaşım Alt } \\
\text { Boyutu }\end{array}$ & $\begin{array}{r}\text { Aile ile beraber } \\
\text { Öğrenci evi } \\
\text { Devlet yurdu } \\
\text { Özel yurt } \\
\text { Toplam }\end{array}$ & $\begin{array}{r}99 \\
8 \\
2 \\
20 \\
129 \\
\end{array}$ & $\begin{array}{l}64,47 \\
68,06 \\
58,75 \\
67,00\end{array}$ & 3 & , 187 & ,980 \\
\hline $\begin{array}{l}\text { PÇE-Planlı } \\
\text { Yaklaşım Alt } \\
\text { Boyutu }\end{array}$ & $\begin{array}{r}\text { Aile ile beraber } \\
\text { Öğrenci evi } \\
\text { Devlet yurdu } \\
\text { Özel yurt } \\
\text { Toplam }\end{array}$ & $\begin{array}{r}99 \\
8 \\
2 \\
20 \\
129\end{array}$ & $\begin{array}{l}63,68 \\
66,00 \\
86,50 \\
68,98\end{array}$ & 3 & 1,025 & ,795 \\
\hline
\end{tabular}

Tablo 9 incelendiğinde; okul öncesi öğretmen adaylarının öğrenim görürken kalınan yer değişkenine göre Problem Çözme Envanteri genelinden $\left(X^{2}=, 580 ; p>.05\right)$, Aceleci Yaklaşım $\left(X^{2}=3,396, ; p>.05\right)$, Düşünen Yaklaşım $\left(X^{2}=, 580 ; p>.05\right)$, Kaçıngan Yaklaşım $\left(X^{2}=3,849\right.$; $p>.05)$, Değerlendirici Yaklaşım $\left(X^{2}=1,279 ; p>.05\right)$, Kendine Güvenli Yaklaşım $\left(X^{2}=, 187\right.$; $\mathrm{p}>.05)$, Planlı Yaklaşım $\left(\mathrm{X}^{2}=1,025 ; \mathrm{p}>.05\right)$ alt boyutlarından aldıkları puanlar arasındaki farkın istatistiksel olarak anlamlı bulunmadığı görülmektedir. 
Yaşar Ekici, F. (2017). Examination of preservice preschool teachers' level of problem solving and social skills. International Journal of Social Sciences and Education Research, 3(1), 16-38.

Tablo 10. Katılımcıların Sosyal Beceri Envanteri'nden aldıkları puanların öğrenim görürken kalınan yer değişkenine göre farklılaşıp farklılaşmadığını belirlemek üzere yapılan Kruskal Wallis-H Test sonuçları

\begin{tabular}{|c|c|c|c|c|c|c|}
\hline Ölçekler & $\begin{array}{c}\text { Öğrenim } \\
\text { görürken kalı- } \\
\text { nan yer }\end{array}$ & $\mathbf{N}$ & Sira Ort. & SD & $\mathrm{X}^{2}$ & $\mathbf{P}$ \\
\hline \multirow{5}{*}{$\begin{array}{l}\text { SOSYAL BE- } \\
\text { CERİ EN- } \\
\text { VANTERİ } \\
\text { GENELİ }\end{array}$} & Aile ile beraber & 103 & 66,24 & \multirow{5}{*}{3} & \multirow{5}{*}{8,690} & \multirow{5}{*}{, $034 *$} \\
\hline & Öğrenci evi & 8 & 48,75 & & & \\
\hline & Devlet yurdu & 2 & 48,50 & & & \\
\hline & Özel yurt & 21 & 89,24 & & & \\
\hline & Toplam & 134 & & & & \\
\hline \multirow{5}{*}{$\begin{array}{l}\text { SBE-Duyuşsal } \\
\text { Anlatımcılık } \\
\text { Alt Boyutu }\end{array}$} & Aile ile beraber & 103 & 68,34 & \multirow{5}{*}{3} & \multirow{5}{*}{11,574} & \multirow{5}{*}{, $009 *$} \\
\hline & Öğrenci evi & 8 & 26,38 & & & \\
\hline & Devlet yurdu & 2 & 54,00 & & & \\
\hline & Özel yurt & 21 & 80,31 & & & \\
\hline & Toplam & 134 & & & & \\
\hline \multirow{5}{*}{$\begin{array}{l}\text { SBE-Duyuşsal } \\
\text { Duyarlılık Alt } \\
\text { Boyutu }\end{array}$} & Aile ile beraber & 103 & 68,00 & \multirow{5}{*}{3} & \multirow{5}{*}{6,161} & \multirow{5}{*}{, 104} \\
\hline & Öğrenci evi & 8 & 48,44 & & & \\
\hline & Devlet yurdu & 2 & 20,00 & & & \\
\hline & Özel yurt & 21 & 76,81 & & & \\
\hline & Toplam & 134 & & & & \\
\hline \multirow{5}{*}{$\begin{array}{l}\text { SBE-Duyuşsal } \\
\text { Kontrol Alt } \\
\text { Boyutu }\end{array}$} & Aile ile beraber & 103 & 65,67 & \multirow{5}{*}{3} & \multirow{5}{*}{6,305} & \multirow{5}{*}{,098 } \\
\hline & Öğrenci evi & 8 & 48,19 & & & \\
\hline & Devlet yurdu & 2 & 60,50 & & & \\
\hline & Özel yurt & 21 & 84,48 & & & \\
\hline & Toplam & 134 & & & & \\
\hline \multirow{5}{*}{$\begin{array}{l}\text { SBE-Sosyal } \\
\text { Anlatımcılık } \\
\text { Alt Boyutu }\end{array}$} & Aile ile beraber & 103 & 66,00 & \multirow{5}{*}{3} & \multirow{5}{*}{1,287} & \multirow{5}{*}{, 732} \\
\hline & Öğrenci evi & 8 & 63,25 & & & \\
\hline & Devlet yurdu & 2 & 74,25 & & & \\
\hline & Özel yurt & 21 & 75,86 & & & \\
\hline & Toplam & 134 & & & & \\
\hline \multirow{5}{*}{$\begin{array}{l}\text { SBE-Sosyal } \\
\text { Duyarlılık Alt } \\
\text { Boyutu }\end{array}$} & Aile ile beraber & 103 & 65,67 & \multirow{5}{*}{3} & \multirow{5}{*}{5,916} & \multirow{5}{*}{, 116} \\
\hline & Öğrenci evi & 8 & 58,00 & & & \\
\hline & Devlet yurdu & 2 & 32,25 & & & \\
\hline & Özel yurt & 21 & 83,45 & & & \\
\hline & Toplam & 134 & & & & \\
\hline \multirow{5}{*}{$\begin{array}{l}\text { SBE-Sosyal } \\
\text { Kontrol Alt } \\
\text { Boyutu }\end{array}$} & Aile ile beraber & 103 & 65,23 & \multirow{5}{*}{3} & \multirow{5}{*}{3,827} & \multirow{5}{*}{, 281} \\
\hline & Öğrenci evi & 8 & 59,50 & & & \\
\hline & Devlet yurdu & 2 & 60,50 & & & \\
\hline & Özel yurt & 21 & 82,33 & & & \\
\hline & Toplam & 134 & & & & \\
\hline
\end{tabular}

Tablo 10 incelendiğinde; okul öncesi öğretmen adaylarının öğrenim görürken kalınan yer değişkenine göre Duyuşsal Duyarlık $\left(X^{2}=6,161 ; p>.05\right)$, Duyuşsal Kontrol $\left(X^{2}=6,305 ; p>.05\right)$, Sosyal Anlatımc1lık $\left(X^{2}=1,287 ; p>.05\right)$, Sosyal Duyarlık $\left(X^{2}=5,916 ; p>.05\right)$ ve Sosyal Kontrol $\left(X^{2}=3,827 ; p>.05\right)$ alt boyutlarından aldıkları puanlar arasındaki farkın istatistiksel olarak anlamlı bulunmadığı görülmektedir. Okul öncesi öğretmen adaylarının öğrenim görürken kalınan yer değişkenine göre Sosyal Beceri Envanteri genelinden $\left(X^{2}=8,690 ; p<05\right)$ ve Duyuşsal Anlatımc1lık $\left(\mathrm{X}^{2}=1,173, ; \mathrm{p}<.05\right)$ alt boyutundan aldıkları puanlar arasındaki farkın istatistiksel olarak anlamlı olduğu görülmektedir. Bu işlemin ardından belirlenen anlamlı farklılığın hangi gruplardan kaynaklandığını belirlemek üzere tamamlayıcı karşılaştırma tekniklerine geçilmiştir. Bu amaçla kullanılan özel bir test tekniği bulunmadığından ikili karşılaştırmalarda tercih 
Yaşar Ekici, F. (2017). Okul öncesi öğretmen adaylarının problem çözme ve sosyal beceri düzeylerinin incelenmesi. International Journal of Social Sciences and Education Research, 3(1), 16-38.

edilen Mann Whitney-U Testi uygulanmış ve gruplar arasında tek tek karşılaştırmaya gidilmiştir. Elde edilen bulgular, aşağıda tablolar halinde sunulmuştur.

Tablo 11. Okul öncesi öğretmen adaylarının Sosyal Beceri Envanteri genelinden ve Duyuşsal Anlatımcılık alt boyutundan aldıkları puanların öğrenim görürken kalınan yer değişkenine göre hangi gruplar arasında farklılaşıp farklılaşmadığını belirlemek üzere yapılan Mann Withney U testi sonuçları

\begin{tabular}{|c|c|c|c|c|c|c|c|}
\hline Alt Boyut & $\begin{array}{l}\text { Öğrenim görür- } \\
\text { ken kalınan yer }\end{array}$ & $\mathbf{N}$ & Sira Ort. & Sira Topl. & $\mathbf{Z}$ & $\mathbf{U}$ & $\mathbf{P}$ \\
\hline SBE Genel & $\begin{array}{l}\text { Aile ile birlikte } \\
\text { özel yurt } \\
\text { Toplam }\end{array}$ & $\begin{array}{c}105 \\
21 \\
126\end{array}$ & $\begin{array}{l}59,97 \\
81,17\end{array}$ & $\begin{array}{l}6296,50 \\
1704,50\end{array}$ & $-2,429$ & 731,500 &, $015^{*}$ \\
\hline SBE-Genel & $\begin{array}{l}\text { Öğrenci evi } \\
\text { özel yurt } \\
\text { Toplam }\end{array}$ & $\begin{array}{c}8 \\
21 \\
29\end{array}$ & $\begin{array}{c}8,81 \\
17,36\end{array}$ & $\begin{array}{c}70,50 \\
364,50\end{array}$ & $-2,416$ & 34,500 &, $016^{*}$ \\
\hline $\begin{array}{l}\text { SBE-Duyuş- } \\
\text { sal } \\
\text { Anlatımcılık } \\
\text { alt boyutu }\end{array}$ & $\begin{array}{l}\text { Aile ile beraber } \\
\text { öğrenci evi } \\
\text { Toplam }\end{array}$ & $\begin{array}{c}103 \\
8 \\
114\end{array}$ & $\begin{array}{l}58,50 \\
23,88\end{array}$ & $\begin{array}{c}6025,00 \\
191,00\end{array}$ & $-2,933$ & 155,000 & ,003* \\
\hline $\begin{array}{l}\text { SBE-Duyuş- } \\
\text { sal } \\
\text { Anlatımcılık } \\
\text { alt boyutu }\end{array}$ & $\begin{array}{l}\text { Öğrenci evi } \\
\text { özel yurt } \\
\text { Toplam }\end{array}$ & $\begin{array}{c}8 \\
21 \\
29\end{array}$ & $\begin{array}{c}6,25 \\
18,33\end{array}$ & $\begin{array}{c}50,00 \\
385,00\end{array}$ & $-3,424$ & 14,000 & ,001* \\
\hline
\end{tabular}

Tablo 11 incelendiğinde görülmektedir ki; okul öncesi öğretmen adaylarının Sosyal Beceri Envanteri genelinden aldıkları puanlarda gruplar arasındaki fark anlamlı bulunmuştur $(p<, 05)$. Buna göre sıra ortalamalarına bakıldığında; öğrenim görürken özel yurtta kalan katılımcıların (sıra ort. $=81,17)$ öğrenim görürken aile ile birlikte kalan katılımcılara (sıra ort. $=59,97$ ) oranla Sosyal Beceri Envanteri genelinden daha yüksek puan aldıkları görülmektedir. Öğrenim görürken özel yurtta kalan katılımcıların (sıra ort.=17,36) öğrenim görürken öğrenci evinde kalan katılımcılara (sıra ort. $=8,81$ ) oranla Sosyal Beceri Envanteri genelinden daha yüksek puan aldıkları görülmektedir.

Bunun yanında, okul öncesi öğretmen adaylarının Duyuşsal Anlatımcılık alt boyutundan aldıkları puanlarda da gruplar arasındaki fark anlamlı bulunmuştur $(\mathrm{p}<, 05)$. Buna göre sıra ortalamalarına bakıldığında; öğrenim görürken aile ile beraber kalan katılımcıların (sıra ort.= 58,50), öğrenim görürken öğrenci evinde kalan katılımcılara (sıra ort.=23,88) oranla Duyuşsal Anlatımcılık alt boyutunda daha yüksek puan aldıkları görülmektedir. Öğrenim görürken özel yurtta kalan katılımcıların (sıra ort.=18,33), öğrenim görürken öğrenci evinde kalan katılımcılara (sıra ort. $=6,25$ ) oranla Duyuşsal Anlatımcılık alt boyutunda daha yüksek puan aldıkları görülmektedir. 
Yaşar Ekici, F. (2017). Examination of preservice preschool teachers' level of problem solving and social skills. International Journal of Social Sciences and Education Research, 3(1), 16-38.

Tablo 12. Katılımcıların Problem Çözme Envanteri’nden aldıkları puanların gelir düzeyi değişkenine göre farklılaşıp farklılaşmadığını belirlemek üzere yapılan Kruskal Wallis-H test sonuçları

\begin{tabular}{|c|c|c|c|c|c|c|}
\hline Ölçekler & Gelir Düzeyi & $\mathbf{N}$ & Sira Ort. & SD & $\mathrm{X}^{2}$ & $\mathbf{P}$ \\
\hline PROBLEM & Düşük & 4 & 80,25 & & & \\
\hline ÇÖZME EN- & Orta & 113 & 62,79 & & & \\
\hline VANTERİ & Yüksek & 12 & 80,75 & 2 & 3,194 & ,203 \\
\hline GENELİ & Toplam & 129 & & & & \\
\hline PÇE-Aceleci & Düşük & 4 & 99,88 & & & \\
\hline Yaklaşım Alt & Orta & 113 & 62,48 & & & \\
\hline \multirow[t]{2}{*}{ Boyutu } & Yüksek & 12 & 77,13 & 2 & 5,291 & ,071 \\
\hline & Toplam & 129 & & & & \\
\hline PÇE-Düşünen & Düşük & 4 & 74,63 & & & \\
\hline Yaklaşım Alt & Orta & 113 & 63,75 & & & \\
\hline \multirow[t]{2}{*}{ Boyutu } & Yüksek & 12 & 73,54 & 2 & 1,021 & ,600 \\
\hline & Toplam & 129 & & & & \\
\hline PÇE-Kaçın- & Düşük & 4 & 74,13 & & & \\
\hline gan Yaklaşım & Orta & 113 & 62,16 & & & \\
\hline \multirow[t]{2}{*}{ Alt Boyutu } & Yüksek & 12 & 88,67 & 2 & 5,756 &, 056 \\
\hline & Toplam & 129 & & & & \\
\hline PÇE-Değer- & Düşük & 4 & 73,25 & & & \\
\hline lendirici & Orta & 113 & 64,52 & & & \\
\hline Yaklaşım Alt & Yüksek & 12 & 66,79 & 2 & ,244 & ,885 \\
\hline Boyutu & Toplam & 129 & & & & \\
\hline PÇE-Kendine & Düşük & 4 & 69,88 & & & \\
\hline Güvenli & Orta & 113 & 64,34 & & & \\
\hline Yaklaşım Alt & Yüksek & 12 & 69,63 & 2 & ,288 & ,866 \\
\hline Boyutu & Toplam & 129 & & & & \\
\hline PÇE-Planlı & Düşük & 4 & 56,13 & & & \\
\hline Yaklaşım Alt & Orta & 113 & 64,29 & & & \\
\hline \multirow[t]{2}{*}{ Boyutu } & Yüksek & 12 & 74,67 & 2 & 1,078 & ,583 \\
\hline & Toplam & 129 & & & & \\
\hline
\end{tabular}

Tablo 12 incelendiğinde; okul öncesi öğretmen adaylarının gelir düzeyine göre Problem Çözme Envanteri genelinden $\left(X^{2}=3,194 ; p>.05\right)$, Aceleci Yaklaşım $\left(X^{2}=5,291, ; p>.05\right)$, Düşünen Yaklaşım $\left(X^{2}=1,021 ; p>.05\right)$, Kaçıngan Yaklaşım $\left(X^{2}=5,756 ; p>.05\right)$, Değerlendirici Yaklaşım $\left(X^{2}=, 244 ; p>.05\right)$, Kendine Güvenli Yaklaşım $\left(X^{2}=, 288 ; p>.05\right)$, Planlı Yaklaşım $\left(\mathrm{X}^{2}=1,078 ; \mathrm{p}>.05\right)$ alt boyutlarından aldıkları puanlar arasındaki farkın istatistiksel olarak anlamlı bulunmadığı görülmektedir.

Tablo 13 incelendiğinde; okul öncesi öğretmen adaylarının gelir düzeyi değişkenine göre Duyuşsal Duyarlık ( $\left.X^{2}=5,015 ; p>.05\right)$, Duyuşsal Kontrol $\left(X^{2}=5,829 ; p>.05\right)$, Sosyal Anlatımc1l1k $\left(X^{2}=, 272 ; p>.05\right)$, Sosyal Duyarlık $\left(X^{2}=, 778 ; p>.05\right)$ ve Sosyal Kontrol $\left(X^{2}=2,070\right.$; $\mathrm{p}>.05)$ alt boyutlarından aldıkları puanlar arasındaki farkın istatistiksel olarak anlamlı bulunmadığı görülmektedir. Okul öncesi öğretmen adaylarının gelir düzeyi değişkenine göre Sosyal Beceri Envanteri genelinden $\left(X^{2}=6,465 ; p<05\right)$ ve Duyuşsal Anlatımcılık $\left(X^{2}=7,620 ; p<.05\right)$ alt boyutundan aldıkları puanlar arasındaki farkın istatistiksel olarak anlamlı olduğu görülmektedir. Bu işlemin ardından belirlenen anlamlı farklılığın hangi gruplardan kaynaklandığını belirlemek üzere tamamlayıcı karşılaştırma tekniklerine geçilmiştir. Bu amaçla kullanılan özel bir test tekniği bulunmadığından ikili karşılaştırmalarda tercih edilen Mann Whitney-U Testi 
Yaşar Ekici, F. (2017). Okul öncesi öğretmen adaylarının problem çözme ve sosyal beceri düzeylerinin incelenmesi. International Journal of Social Sciences and Education Research, 3(1), 16-38.

uygulanmış ve gruplar arasında tek tek karşılaştırmaya gidilmiştir. Elde edilen bulgular, aşağıda tablolar halinde sunulmuştur.

Tablo 13. Katılımcıların Sosyal Beceri Envanteri'nden aldıkları puanların gelir düzeyi değişkenine göre farklılaşıp farklılaşmadığını belirlemek üzere yapılan Kruskal Wallis-H test sonuçları

\begin{tabular}{|c|c|c|c|c|c|c|}
\hline Ölçekler & Gelir Düzeyi & $\mathbf{N}$ & Sira Ort. & SD & $\mathrm{X}^{2}$ & $\mathbf{P}$ \\
\hline SOSYAL BE- & Düşük & 4 & 26,10 & & & \\
\hline CERİ EN- & Orta & 118 & 69,38 & & & \\
\hline VANTERİ & Yüksek & 12 & 77,42 & 2 & 6,465 & ,039* \\
\hline GENELI & Toplam & 134 & & & & \\
\hline \multirow{4}{*}{$\begin{array}{l}\text { SBE-Duyuşsal } \\
\text { Anlatımcılık } \\
\text { Alt Boyutu }\end{array}$} & Düşük & 4 & 19,50 & & & \\
\hline & Orta & 118 & 67,74 & & & \\
\hline & Yüksek & 12 & 81,17 & 2 & 7,620 &, $022 *$ \\
\hline & Toplam & 134 & & & & \\
\hline \multirow{4}{*}{$\begin{array}{l}\text { SBE-Duyuşsal } \\
\text { Duyarlılık Alt } \\
\text { Boyutu }\end{array}$} & Düșük & 4 & 28,00 & & & \\
\hline & Orta & 118 & 67,78 & & & \\
\hline & Yüksek & 12 & 77,88 & 2 & 5,015 & ,081 \\
\hline & Toplam & 134 & & & & \\
\hline \multirow{4}{*}{$\begin{array}{l}\text { SBE-Duyuşsal } \\
\text { Kontrol Alt } \\
\text { Boyutu }\end{array}$} & Düsük & 4 & 22,00 & & & \\
\hline & Orta & 118 & 68,48 & & & \\
\hline & Yüksek & 12 & 73,04 & 2 & 5,829 & ,054 \\
\hline & Toplam & 134 & & & & \\
\hline \multirow{4}{*}{$\begin{array}{l}\text { SBE-Sosyal } \\
\text { Anlatımcılık } \\
\text { Alt Boyutu }\end{array}$} & Düşük & 4 & 57,63 & & & \\
\hline & Orta & 118 & 67,73 & & & \\
\hline & Yüksek & 12 & 68,50 & 2 & ,272 & ,873 \\
\hline & Toplam & 134 & & & & \\
\hline \multirow{4}{*}{$\begin{array}{l}\text { SBE-Sosyal } \\
\text { Duyarlılık Alt } \\
\text { Boyutu }\end{array}$} & Düşük & 4 & 54,00 & & & \\
\hline & Orta & 118 & 67,34 & & & \\
\hline & Yüksek & 12 & 73,54 & 2 & ,778 & 678 \\
\hline & Toplam & 134 & & & & \\
\hline \multirow{4}{*}{$\begin{array}{l}\text { SBE-Sosyal } \\
\text { Kontrol Alt } \\
\text { Boyutu }\end{array}$} & Düşük & 4 & 44,75 & & & \\
\hline & Orta & 118 & 69,08 & & & \\
\hline & Yüksek & 12 & 59,58 & 2 & 2,070 &, 355 \\
\hline & Toplam & 134 & & & & \\
\hline
\end{tabular}

Tablo 14. Okul öncesi öğretmen adaylarının Sosyal Beceri Envanteri genelinden ve Duyuşsal Anlatımcılık alt boyutundan aldıkları puanların gelir düzeyi değişkenine göre hangi gruplar arasında farklılaşıp farklılaşmadığını belirlemek üzere yapılan Mann Withney U testi sonuçları

\begin{tabular}{|c|c|c|c|c|c|c|c|}
\hline Alt Boyut & Gelir Düzeyi & $\mathbf{N}$ & Sira Ort. & Sira Topl. & $\mathbf{Z}$ & $\mathbf{U}$ & $\mathbf{P}$ \\
\hline SBE Genel & $\begin{array}{l}\text { Düşük } \\
\text { Orta } \\
\text { Toplam }\end{array}$ & $\begin{array}{c}5 \\
119 \\
124\end{array}$ & $\begin{array}{l}24,00 \\
64,12\end{array}$ & $\begin{array}{c}120,00 \\
7630,00\end{array}$ & $-2,445$ & 105,000 & ,014* \\
\hline SBE-Genel & $\begin{array}{l}\text { Düşük } \\
\text { Yüksek } \\
\text { Toplam }\end{array}$ & $\begin{array}{c}5 \\
12 \\
17\end{array}$ & $\begin{array}{c}5,10 \\
10,63\end{array}$ & $\begin{array}{c}25,50 \\
127,50\end{array}$ & $-2,057$ & 10,500 &, $040^{*}$ \\
\hline $\begin{array}{l}\text { SBE-Duyuş- } \\
\text { sal } \\
\text { Anlatımcılık } \\
\text { alt boyutu }\end{array}$ & $\begin{array}{l}\text { Düşük } \\
\text { Orta } \\
\text { Toplam }\end{array}$ & $\begin{array}{c}4 \\
118 \\
122\end{array}$ & $\begin{array}{l}17,63 \\
62,99\end{array}$ & $\begin{array}{c}70,50 \\
7432,50\end{array}$ & $-2,526$ & 60,500 &, $012 *$ \\
\hline $\begin{array}{l}\text { SBE-Duyuş- } \\
\text { sal Anlatımcı- } \\
\text { lık alt boyutu }\end{array}$ & $\begin{array}{l}\text { Düşük } \\
\text { Yüksek } \\
\text { Toplam }\end{array}$ & $\begin{array}{c}4 \\
12 \\
16\end{array}$ & $\begin{array}{l}4,38 \\
9,88\end{array}$ & $\begin{array}{c}17,50 \\
118,50\end{array}$ & $-2,004$ & 7,500 &, $045^{*}$ \\
\hline
\end{tabular}


Yaşar Ekici, F. (2017). Examination of preservice preschool teachers' level of problem solving and social skills. International Journal of Social Sciences and Education Research, 3(1), 16-38.

Tablo 14 incelendiğinde görülmektedir ki; okul öncesi öğretmen adaylarının Sosyal Beceri Envanteri genelinden aldıkları puanlarda gruplar arasındaki fark anlamlı bulunmuştur $(\mathrm{p}<, 05)$. Buna göre sıra ortalamalarına bakıldığında; gelir düzeyi orta olan katılımcıların (sıra ort. $=64,12)$ gelir düzeyi düşük olan katılımcılara (sıra ort.=24,00) oranla Sosyal Beceri Envanteri genelinden daha yüksek puan aldıkları görülmektedir. Gelir düzeyi yüksek olan katılımcıların (sıra ort. $=10,63$ ) gelir düzeyi düşük olan katılımcılara (sıra ort. $=5,10$ ) oranla Sosyal Beceri Envanteri genelinden daha yüksek puan aldıkları görülmektedir.

Bunun yanında, okul öncesi öğretmen adaylarının Duyuşsal Anlatımcılık alt boyutundan aldıkları puanlarda da gruplar arasındaki fark anlamlı bulunmuştur $(\mathrm{p}<, 05)$. Buna göre sıra ortalamalarına bakıldığında; gelir düzeyi orta olan katılımcıların (sıra ort.=62,99), gelir düzeyi düşük olan katılımcılara (sıra ort. $=17,63$ ) oranla Duyuşsal Anlatımcılık alt boyutunda daha yüksek puan aldıkları görülmektedir. Gelir düzeyi yüksek olan katılımcıların (sıra ort.=9,88), gelir düzeyi düşük olan katılımcılara (sıra ort. $=4,38$ ) oranla Duyuşsal Anlatımcılık alt boyutunda daha yüksek puan aldıkları görülmektedir. 
Yaşar Ekici, F. (2017). Okul öncesi öğretmen adaylarının problem çözme ve sosyal beceri düzeylerinin incelenmesi. International Journal of Social Sciences and Education Research, 3(1), 16-38.

Tablo 15. Katılımcıların Problem Çözme Envanteri'nden aldıkları puanların kardeş sayısı değişkenine göre farklılaşıp farklılaşmadığını belirlemek üzere yapılan Kruskal Wallis-H test sonuçları

\begin{tabular}{|c|c|c|c|c|c|c|}
\hline Ölçekler & $\begin{array}{c}\text { Kardeş Sa- } \\
\text { yısı }\end{array}$ & $\mathbf{N}$ & Sira Ort. & SD & $\mathbf{X}^{2}$ & $\mathbf{P}$ \\
\hline & Kardeșim yok & 5 & 60,10 & & & \\
\hline PROBLEM & 1 & 17 & 78,59 & & & \\
\hline ÇÖZME & 2 & 40 & 57,98 & 5 & 4,696 & , 454 \\
\hline ENVAN- & 3 & 38 & 63,24 & & & \\
\hline TERI GE- & 4 & 19 & 63,82 & & & \\
\hline \multirow[t]{2}{*}{ NELI } & 5 & 9 & 76,11 & & & \\
\hline & Toplam & 128 & & & & \\
\hline PÇE-Aceleci & Kardeşim yok & 5 & 61,50 & & & \\
\hline Yaklaşım & 1 & 17 & 68,65 & & & \\
\hline \multirow{5}{*}{ Alt Boyutu } & 2 & 40 & 61,35 & 5 & ,889 & ,971 \\
\hline & 3 & 38 & 64,41 & & & \\
\hline & 4 & 19 & 64,95 & & & \\
\hline & 5 & 9 & 71,78 & & & \\
\hline & Toplam & 128 & & & & \\
\hline PÇE-Düşü- & Kardeşim yok & 5 & 78,60 & & & \\
\hline nen Yakla- & 1 & 17 & 73,82 & & & \\
\hline şım Alt Bo- & 2 & 40 & 61,58 & 5 & 6,010 &, 305 \\
\hline \multirow{4}{*}{ yutu } & 3 & 38 & 56,55 & & & \\
\hline & 4 & 19 & 65,87 & & & \\
\hline & 5 & 9 & 82,72 & & & \\
\hline & Toplam & 128 & & & & \\
\hline \multirow{7}{*}{$\begin{array}{l}\text { PÇE-Kaçın- } \\
\text { gan Yakla- } \\
\text { şım Alt Bo- } \\
\text { yutu }\end{array}$} & Kardeşim yok & 5 & 63,30 & & & \\
\hline & 1 & 17 & 72,79 & & & \\
\hline & 2 & 40 & 52,54 & 5 & 6,606 &, 252 \\
\hline & 3 & 38 & 67,96 & & & \\
\hline & 4 & 19 & 71,26 & & & \\
\hline & 5 & 9 & 73,78 & & & \\
\hline & Toplam & 128 & & & & \\
\hline \multirow{7}{*}{$\begin{array}{l}\text { PÇE-Değer- } \\
\text { lendirici } \\
\text { Yaklaşım } \\
\text { Alt Boyutu }\end{array}$} & Kardeşim yok & 5 & 70,80 & & & \\
\hline & 1 & 17 & 75,56 & & & \\
\hline & 2 & 40 & 66,33 & 5 & 2,735 & ,741 \\
\hline & 3 & 38 & 59,70 & & & \\
\hline & 4 & 19 & 60,53 & & & \\
\hline & 5 & 9 & 60,67 & & & \\
\hline & Toplam & 128 & & & & \\
\hline \multirow{7}{*}{$\begin{array}{l}\text { PÇE-Ken- } \\
\text { dine Güvenli } \\
\text { Yaklaşım } \\
\text { Alt Boyutu }\end{array}$} & Kardeşim yok & 5 & 55,20 & & & \\
\hline & 1 & 17 & 74,15 & & & \\
\hline & 2 & 40 & 60,18 & 5 & 4,923 & ,425 \\
\hline & 3 & 38 & 61,22 & & & \\
\hline & 4 & 19 & 64,53 & & & \\
\hline & 5 & 9 & 84,44 & & & \\
\hline & Toplam & 128 & & & & \\
\hline \multirow{7}{*}{$\begin{array}{l}\text { PÇE-Planlı } \\
\text { Yaklaşım } \\
\text { Alt Boyutu }\end{array}$} & Kardeşim yok & 5 & 64,20 & & & \\
\hline & 1 & 17 & 74,79 & & & \\
\hline & 2 & 40 & 63,45 & 5 & 2,079 & ,838 \\
\hline & 3 & 38 & 59,66 & & & \\
\hline & 4 & 19 & 66,32 & & & \\
\hline & 5 & 9 & 66,50 & & & \\
\hline & Toplam & 128 & & & & \\
\hline
\end{tabular}


Yaşar Ekici, F. (2017). Examination of preservice preschool teachers' level of problem solving and social skills. International Journal of Social Sciences and Education Research, 3(1), 16-38.

Tablo 15 incelendiğinde; okul öncesi öğretmen adaylarının kardeş sayısı değişkenine göre Problem Çözme Envanteri genelinden $\left(X^{2}=4,696 ; \mathrm{p}>.05\right)$, Aceleci Yaklaşım $\left(X^{2}=, 889\right.$,; $p>.05)$, Düşünen Yaklaşım $\left(X^{2}=6,010 ; p>.05\right)$, Kaçıngan Yaklaşım $\left(X^{2}=6,606 ; p>.05\right)$, Değerlendirici Yaklaşım $\left(X^{2}=2,735 ; p>.05\right)$, Kendine Güvenli Yaklaşım $\left(X^{2}=4,923 ; p>.05\right)$, Planlı Yaklaşım $\left(\mathrm{X}^{2}=2,079 ; \mathrm{p}>.05\right)$ alt boyutlarından aldıkları puanlar arasındaki farkın istatistiksel olarak anlamlı bulunmadığı görülmektedir.

Tablo 16. Katılımcıların Sosyal Beceri Envanteri'nden aldıkları puanların kardeş sayısı değişkenine göre farklılaşıp farklılaşmadığını belirlemek üzere yapılan Kruskal Wallis-H test sonuçları

\begin{tabular}{|c|c|c|c|c|c|c|}
\hline Ölçekler & Kardeş sayısı & $\mathbf{N}$ & Sira Ort. & SD & $\mathrm{X}^{2}$ & $\mathbf{P}$ \\
\hline & Kardeşim yok & 6 & 64,08 & & & \\
\hline SOSYAL BE- & 1 & 16 & 65,24 & & & \\
\hline CERİ EN- & 2 & 44 & 63,23 & 5 & 4,477 & ,483 \\
\hline VANTERİ & 3 & 39 & 66,65 & & & \\
\hline \multirow[t]{3}{*}{ GENELİ } & 4 & 19 & 80,53 & & & \\
\hline & 5 & 10 & 84,45 & & & \\
\hline & Toplam & 134 & & & & \\
\hline SBE-Duyuşsal & Kardeşim yok & 6 & 64,08 & & & \\
\hline Anlatımcilık & 1 & 16 & 65,24 & & & \\
\hline \multirow[t]{5}{*}{ Alt Boyutu } & 2 & 44 & 63,23 & 5 & 1,534 & 909 \\
\hline & 3 & 39 & 66,65 & & & \\
\hline & 4 & 19 & 80,53 & & & \\
\hline & 5 & 10 & 84,45 & & & \\
\hline & Toplam & 134 & & & & \\
\hline SBE-Duyuşsal & Kardeşim yok & 6 & 70,00 & & & \\
\hline Duyarlılık Alt & 1 & 16 & 65,72 & & & \\
\hline \multirow[t]{5}{*}{ Boyutu } & 2 & 44 & 60,76 & 5 & 3,384 & ,641 \\
\hline & 3 & 39 & 67,95 & & & \\
\hline & 4 & 19 & 76,68 & & & \\
\hline & 5 & 10 & 79,30 & & & \\
\hline & Toplam & 134 & & & & \\
\hline SBE-Duyuşsal & Kardeşim yok & 6 & 69,17 & & & \\
\hline Kontrol Alt & 1 & 16 & 58,78 & & & \\
\hline \multirow[t]{5}{*}{ Boyutu } & 2 & 44 & 58,67 & 5 & 9,161 & 103 \\
\hline & 3 & 39 & 70,17 & & & \\
\hline & 4 & 19 & 74,50 & & & \\
\hline & 5 & 10 & 95,60 & & & \\
\hline & Toplam & 134 & & & & \\
\hline SBE-Sosyal & Kardeşim yok & 6 & 50,08 & & & \\
\hline Anlatımcılık & 1 & 16 & 68,50 & & & \\
\hline \multirow[t]{5}{*}{ Alt Boyutu } & 2 & 44 & 57,83 & 5 & 8,788 & ,118 \\
\hline & 3 & 39 & 69,01 & & & \\
\hline & 4 & 19 & 82,32 & & & \\
\hline & 5 & 10 & 84,85 & & & \\
\hline & Toplam & 134 & & & & \\
\hline SBE-Sosyal & Kardeşim yok & 6 & 73,25 & & & \\
\hline Duyarlılık Alt & 1 & 16 & 68,88 & & & \\
\hline \multirow[t]{5}{*}{ Boyutu } & 2 & 44 & 62,83 & 5 & 3,486 &, 625 \\
\hline & 3 & 39 & 63,38 & & & \\
\hline & 4 & 19 & 76,89 & & & \\
\hline & 5 & 10 & 80,60 & & & \\
\hline & Toplam & 134 & & & & \\
\hline SBE-Sosyal & Kardeşim yok & 6 & 71,17 & & & \\
\hline Kontrol Alt & 1 & 16 & 71,72 & & & \\
\hline \multirow[t]{5}{*}{ Boyutu } & 2 & 44 & 68,28 & 5 & 1,006 & ,962 \\
\hline & 3 & 39 & 62,87 & & & \\
\hline & 4 & 19 & 67,66 & & & \\
\hline & 5 & 10 & 72,85 & & & \\
\hline & Toplam & 134 & & & & \\
\hline
\end{tabular}


Yaşar Ekici, F. (2017). Okul öncesi öğretmen adaylarının problem çözme ve sosyal beceri düzeylerinin incelenmesi. International Journal of Social Sciences and Education Research, 3(1), 16-38.

Tablo 16 incelendiğinde; okul öncesi öğretmen adaylarının yaşa göre Sosyal Beceri Envanteri genelinden $\left(X^{2}=4,477 ; p>.05\right)$, Duyuşsal Anlatımcılık $\left(X^{2}=1,534 ; p>.05\right)$, Duyuşsal Duyarlık $\left(X^{2}=3,384 ; p>.05\right)$, Duyuşsal Kontrol $\left(X^{2}=9,161 ; p>.05\right)$, Sosyal Anlatımcıllk $\left(X^{2}=8,788 ; p>.05\right)$, Sosyal Duyarlık $\left(X^{2}=3,486 ; p>.05\right)$ ve Sosyal Kontrol $\left(X^{2}=1,006 ; p>.05\right)$ alt boyutlarından aldıkları puanlar arasındaki farkın istatistiksel olarak anlamlı bulunmadığı görülmektedir.

\subsection{Ikkinci alt amaca ilişkin bulgular}

Araştırmanın ikinci alt amacı okul öncesi öğretmen adaylarının problem çözme beceri düzeyleri ve sosyal beceri düzeyleri arasında anlamlı bir ilişki olup olmadığını belirlemeye yöneliktir. Aşağıda, ikinci alt amaca ilişkin bulgular tablolar halinde sunulmuştur.

Tablo 17. Okul öncesi öğretmen adaylarının Problem Çözme Envanteri genelinden aldıkları puanlarla Sosyal Beceri Envanteri genelinden aldıkları puanlar arasındaki ilişkiyi belirlemek üzere yapılan Pearson Çarpım Moment Korelasyon Analizi sonuçları

\begin{tabular}{llll}
\hline Değişken & N & r & p \\
\hline Problem Çözme Envanteri & $\mathbf{1 3 1}$ & & \\
Sosyal Beceri Envanteri & $\mathbf{1 3 0}$ & $\mathbf{- , 0 3 0}$ &, 737 \\
\hline
\end{tabular}

Tablo 17'de görüldügüü gibi Problem Çözme Envanteri genelinden alınan puanlarla Sosyal beceri Envanteri genelinden alınan puanlar arasında istatistiksel açıdan anlamlı bir ilişki saptanmamıştır ( $\mathrm{r}=-, 030 ; \mathrm{p}>.05)$.

\section{Sonuç ve tartışma}

$\mathrm{Bu}$ araştırmadan elde edilen sonuçlar, ilgili araştırmalarla karşılaştırılarak aşağıda sunulmuştur:

$\mathrm{Bu}$ araştırmadan elde edilen sonuca göre okul öncesi öğretmen adaylarının problem çözme becerileri ve sosyal becerileri arasında anlamlı bir ilişki saptanmamıştır. Okul öncesi öğretmen adaylarının problem çözme becerileri yaş değişkenine göre farklılaşmamaktadır. Bundan farklı olarak okul öncesi öğretmen adaylarının sosyal becerileri yaş değişkenine göre farklılaşmaktadır. Buna göre 18-20 yaş arasındaki okul öncesi öğretmen adaylarının sosyal kontrol becerileri, 21-23 yaş, 24-26 yaş ve 33-35 yaş arasındaki okul öncesi öğretmen adaylarının sosyal kontrol becerilerinden daha yüksektir. 27-29 yaş arasındaki okul öncesi öğretmen adaylarının sosyal kontrol becerileri, 24-26 yaş arasındaki okul öncesi öğretmen adaylarının sosyal kontrol becerilerinden daha yüksektir. Akpınar (2014)'ın yaptığı araştırmada öğretmen adaylarının problem çözme becerilerinde yaş değişkenine göre problem çözmede aceleci yaklaşım becerilerinde anlamlı bir farklılaşma tespit edilmiştir. Analizlerin sonucunda, 19-21 yaş arası öğretmen adaylarının, 26 ve üzeri yaşlardaki öğretmen adaylarına göre aceleci yaklaşım becerilerinin daha yüksek düzeyde oldukları tespit edilmiştir. Dönmez (2010) beden eğitimi ve spor yüksekokul öğrencileriyle gerçekleştirdiği çalışmasında, beden eğitimi ve spor yüksekokulu öğrencilerinin problem çözme becerileriyle farklı yaş düzeyleri arasında anlamlı bir farkl1laşma olduğu tespit edilmiştir. Çağlayan (2007) yaptığı araştırmada, beden eğitimi ve spor yüksekokulu öğrencilerinin problem çözme becerileriyle, yaş değişkeni arasında önemli bir ilişkiye rastlamamıştır. Akpınar (2014)'ın yaptığı çalışmada öğretmen adaylarının yaş değişkenine göre Sosyal Beceri Envanteri alt boyutlarından duyuşsal anlatımcılık, duyuşsal duyarlılık, duyuşsal kontrol, sosyal anlatımcılık ve sosyal duyarlılık alt boyutunda anlamlı bir farkl11ık görülmezken sosyal kontrolde ise anlamlı bir fark bulunmuş ve 19-21 yaş arası öğretmen adayların, 22-25 yaş arası öğretmen adaylarına göre sosyal kontrol becerilerinin daha yüksek 
Yaşar Ekici, F. (2017). Examination of preservice preschool teachers' level of problem solving and social skills. International Journal of Social Sciences and Education Research, 3(1), 16-38.

düzeyde oldukları görülmüştür. Kırılmazkaya (2010) ilköğretim fen bilgisi ve sınıf öğretmen adaylarının sosyal beceri puanlarında ve Akpınar (2010) spor federasyonunda çalışanların sosyal beceri puanlarında yaş değişkeninin bir farklılık oluşturmadığını ifade etmişlerdir.

$\mathrm{Bu}$ araştırmanın bir diğer sonucuna göre, okul öncesi öğretmen adaylarının problem çözme becerileri sınıf değişkenine göre farklılaşmamaktadır. Bundan farklı olarak okul öncesi öğretmen adaylarının sosyal becerileri sınıf değişkenine göre farklılaşmaktadır. 3.sınıfta öğrenim görmekte olan okul öncesi öğretmen adaylarının sosyal anlatımcılık becerileri, 1. ve 2. sınıfta öğrenim görmekte olan okul öncesi öğretmen adaylarının sosyal anlatımcılık becerilerinden daha yüksektir.

Bu araştırmanın bir diğer sonucuna göre, okul öncesi öğretmen adaylarının problem çözme becerileri öğrenim görürken kalınan yer değişkenine göre farklılaşmamaktadır. Bundan farklı olarak okul öncesi öğretmen adaylarının sosyal becerileri öğrenim görürken kalınan yer değişkenine göre farklılaşmaktadır. Buna göre; öğrenim görürken özel yurtta kalan ve ailesiyle birlikte yaşayan okul öncesi öğretmen adaylarının duyuşsal anlatımcılık becerileri, öğrenim görürken öğrenci evinde kalan okul öncesi öğretmen adaylarının duyuşsalanlatımcılık becerilerinden daha yüksektir. Akpınar (2014)'ın yaptı̆̆ı araştırmada öğretmen adaylarının öğrenim görürken kaldıkları yer değişkenine göre problem çözme envanteri alt boyutlarından, aceleci yaklaşım, düşünen yaklaşım, değerlendirici yaklaşım, kendine güvenli yaklaşım ve planlı yaklaşımda anlamlı bir farklılık görülmezken kaçıngan yaklaşımda ise anlamlı bir fark bulunmuştur. Öğretmen adaylarının öğrenim görürken kalınan yer durumuna göre, kaçıngan yaklaşım beceri düzeyinin aileleri ile beraber kalan öğretmen adaylarında en yüksek olduğu tespit edilmiştir. Çetin (2009) öğrencilerin öğrenimleri sırasında barındıkları yer değişkenine göre sosyal beceri alt boyutlarından duyuşsal anlatımcılık ve sosyal duyarlılık alt boyut puanları arasındaki farkın anlamlı olduğunu, duyuşsal duyarlılık, duyuşsal kontrol, sosyal anlatımcılık, sosyal kontrol ve sosyal beceri toplam puanları arasındaki farkın ise anlamlı olmadığını göstermiştir.

Bu araştırmanın bir diğer sonucuna göre, okul öncesi öğretmen adaylarının problem çözme becerileri gelir düzeyi değişkenine göre farklılaşmamaktadır. Bundan farklı olarak okul öncesi öğretmen adaylarının sosyal becerileri gelir düzeyi değişkenine göre farklılaşmaktadır. Buna göre; gelir düzeyi orta ve yüksek olan okul öncesi öğretmen adaylarının genel sosyal becerileri ve duyuşsal anlatımcılık becerileri, gelir düzeyi düşük olan okul öncesi öğretmen adaylarının genel sosyal becerileri ve duyuşsal anlatımcılık becerilerinden daha yüksektir.

Akpınar (2014), yaptığı araştırmada öğretmen adaylarının sosyal becerileri üzerinde gelir değişkeninin önemli bir faktör olmadığını bulgulamıştır. Yoldaş ve Seven (2007) de sınıf öğretmeni adaylarının sosyal becerileri düzeylerini inceledikleri çalışmalarında sınıf öğretmeni adaylarının gelir ortalamalarında anlamlı bir farklılığa ulaşamamıştır. Çilingir (2006) çalışmasında öğrencilerin gelir düzeyine göre sosyal beceri açısından anlamlı fark olduğunu, Sosyal Beceri Ölçeği alt boyutlarından Duyuşsal Anlatımcılık, Duyuşsal Duyarlılık, Sosyal Anlatımc1lık ve Sosyal Kontrol boyutları açısından ailenin ekonomik durumlarına göre anlamlı fark olduğunu bulgulamıştır.

$\mathrm{Bu}$ araştırmanın bir diğer sonucuna göre, okul öncesi öğretmen adaylarının problem çözme becerileri ve sosyal becerileri kardeş sayısına göre farklılaşmamaktadır. Girgin, Çetingöz, Ekinci-Vural (2011)'ın çalışmasında öğrencilerin kardeş sayısına göre sosyal beceri puanları incelenmiş ve kardeş sayısı 2 olan öğrencilerin sosyal beceri puanları ile kardeş sayısı 6 ve 
Yaşar Ekici, F. (2017). Okul öncesi öğretmen adaylarının problem çözme ve sosyal beceri düzeylerinin incelenmesi. International Journal of Social Sciences and Education Research, 3(1), 16-38.

daha fazla olan öğrencilerin sosyal beceri puanları arasında ölçeğin sosyal duyarlılık alt boyutunda kardeş sayısı 2 olanların lehine anlamlı fark olduğu görülmüştür.

\section{Kaynakça}

Acar, N.V. (1980). Grupla Atılganlık Eğitiminin Bireyin Atılganlık Düzeyine Etkisi, Yayımlanmamış Doktora Tezi, Hacettepe Üniversitesi Sosyal Bilimler Enstitüsü. Ankara.

Akkök, F. (1996). İlkögretimde Sosyal Becerilerin Geliştirilmesi, Öğretmen El Kitabl, Ankara: MEB Yayınları.

Akpınar, S. (2010). Spor Federasyonlarında Çalışanların, Sosyal Beceri, İş Doyumu ve Problem Çözme Yeterlilikleri Üzerine Bir Araştırma, Doktora Tezi, Gazi Üniversitesi, Sağlık Bilimleri Enstitüsü, Ankara.

Akpınar, Ş. (2014). Öğretmen Adaylarının Problem Çözme Ve Sosyal Becerilerinin İncelenmesi. Yüksek Lisans Tezi, Kahramanmaraş Sütçü İmam Üniversitesi, Sosyal Bilimler Enstitüsü, Kahramanmaraş.

Alcı, B. (2007). Üniversite Öğrencilerinin Matematik Başarıları ile Algıladıkları Problem Çözme Becerileri, Özyeterlik Algıları, Bilişüstü Özdüzenleme Stratejileri ve ÖSS Sayısal Puanları Arasındaki Açıklayıcı ve Yordayıcı İlişkiler Örüntüsü. Doktora Tezi, Yıldız Teknik Üniversitesi, Sosyal Bilimler Enstitüsü, İstanbul.

Aydın, G. (1985). Sosyal Başarı Eğitimi İle Sosyal Beceri Eğitiminin Çocuklarda Öğrenilmiş Çaresizlik Davranışının Ortadan Kaldırılmasına Etkisi, Yayımlanmamış Doktora Tezi, Hacettepe Üniversitesi Sosyal Bilimler Enstitüsü, Ankara.

Bacanlı, H. (1990). Kendini Ayarlama Becerisinin Çeşitli Değişsenlerle İliş̧kisi, Yayımlanmamış Doktora Tezi, Ankara Üniversitesi Sosyal Bilimler Enstitüsü, Ankara.

Bacanlı, H. (1999). Illköğretimde Rehberlik, Sosyal Beceri Eğitimi. Ankara: Nobel Yayın Dağıtım.

Başaran, İ.E. (1994). Eğitime Giriş. (4. Baskı). Ankara: Kadığlu Matbaası.

Çağlayan, H.S. (2007). Beden Eğitimi ve Spor Yüksekokulu Öğrencilerinin Öğrenme Biçimleri ile Problem Çözme Becerileri Arasındaki İlişkinin İncelenmesi, Doktora Tezi, Gazi Üniversitesi, Ankara.

Çetin, M.Ç. (2009). Beden Ĕgitimi ve Spor Yüksekokulu Öğrencilerinin Karar Verme Stilleri Sosyal Beceri Düzeyleri ve Stresle Başa Çıkma Biçimlerinin Bazı Değişkenler Açısından Karşılaştırmalı Olarak Incelenmesi, Doktora Tezi, Gazi Üniversitesi, Ankara.

Çilingir, A. (2006). Fen Lisesi ile Genel Lise Öğrencilerinin Sosyal Beceri ve Problem Çözme Becerilerinin Karşılaşttrılması, Yüksek Lisans Tezi, Atatürk Üniversitesi, Erzurum.

Dixon, W. A., Heppner, P. P., Anderson, W. P. (1991). Problem-Solving Appraisal, Stress, Hopelessness and Suicide Ideation in A College Population. Journal of Counseling Psychology, 38(1), 5156.

Dönmez, K. H. (2010). Beden Ĕgitimi ve Spor Öğretmenliği Bölümü Öğrencilerinin (1., 2., 3., ve 4. Sinıf) Sosyal Yeterlikleri Ile Problem Çözme Becerileri Arasındaki İlişkinin İncelenmesi, Yüksek Lisans Tezi, Gazi Üniversitesi Eğitim Bilimler Enstitüsü, Ankara.

Giblin, Robert L, Mitchell M. H. (1995). Introduction to Counseling and Guidance. (Fourth Edition). New Jersey Columbus, Ohio: Merrill an Imprint of Prentice Hall Englewood Cliffs.

Girgin, G. Çetingöz, D., Ekinci-Vural, D .(2011) Ögretmen Adaylarının Sosyal Beceri Düzeylerinin İncelenmesi, Kuramsal Eğitimbilim, 4 (1), 38-49. 
Yaşar Ekici, F. (2017). Examination of preservice preschool teachers' level of problem solving and social skills. International Journal of Social Sciences and Education Research, 3(1), 16-38.

Heppner, P. P., Peterson, C. H. (1982). The Development AndImplications of A Personal-Problem Solving Inventory, Journal of CounselingPsychology, 29, ss. 66-75.

Heppner,P.P., Witty T.E., Dixon W.A. (2004). Problem Solving Appraisal: Helping Normal People Lead Better Lives, The Counseling Psychologist 32(3), 466- 472.

Kaptan, F., Korkmaz, H. (2002). Türkiye'de Hizmet Öncesi Öğretmenlerin Problem Çözme Becerilerine Yönelik Algıları Üzerine Bir İnceleme. Journal Of Qafqaz University, Number 9, 183-188.

Karasar, N. (1999). Bilimsel Araştırma Yöntemi. Ankara: Nobel Yayın Dağıtım.

Kırılmazkaya, G. (2010). İlköğretim Fen Bilgisi ve Sınıf Öğretmen Adaylarının Problem Çözme Becerileri ve Sosyal Becerilerinin Karşılaştırılması. Yüksek Lisans Tezi, Fırat Üniversitesi, Fen Bilimleri Enstitüsü, Elazığ.

Korkut, F. (2002). Lise Öğrencilerinin Problem Çözme Becerileri, Hacettepe Üniversitesi Eğitim Fakültesi Dergisi, 2(1), ss. 11-15.

Miller, M., Nunn, G. D. (2001). Using Group Discussion to Improve Social Problem Solving And Learning. Education, 121 (3): 470-475.

Polat, R. H. (2008). Sinıf Öğretmenliği Öğrencilerinin Bazı Sosyo-Demografik Özellikleri ve Düşünme İhtiyacına Göre Problem Çözme Becerilerinin Incelenmesi. Yüksek Lisans Tezi, Çukurova Üniversitesi, Sosyal Bilimler Enstitüsü, Adana.

Riggio, R. E. (1986). Assesment of Basic Social Skills, Journal of Personality and Social Psychology, 51(3), ss. 649-660

Riggio and Others. (1991). Social and Academic Intelligence; Canceptually Distinet But Overlapping Constructs, Personality and Individual Differrences, p. 695-702.

Serin, O. (2001). Lisans ve Lisansüstü Düzeydeki Fen Grubu Öğrencilerinin Problem Çözme Becerileri, Fen ve Bilgisayara Yönelik Tutumları İle Başarıları Arasındaki İlişki, Dokuz Eylül Üniversitesi, Eğitim Bilimleri Enstitüsü Doktora Tezi, İzmir.

Şahin, H., Kaya, A. Edt. (2004). Kişisel Rehberlik ve Psikolojik Danışmalık, Psikolojik Danışmanlık ve Rehberlik. Ankara: Anı Yayıncılık.

Şahin, N., Şahin, N. H., Heppner, P. P. (1993). Psychometric Proporties of the Problem Solving Inventory in A Group of Turkish University Students. Cognitive Therapy and Research, 17(4), 379-396.

Turan, H. (2010). Sınıf Öğretmenlerinin Yapılandırmacı Özellikleri ile Yaratıcı Düşünme, Problem Çözme Becerileri ve Eleştirel Düşünme Eğilimleri Arasındaki Açıklayıcı İlişkiler Örüntüsü. Yayımlanmamış Doktora Tezi, Yıldız Teknik Üniversitesi, Sosyal Bilimler Enstitüsü, İstanbul.

Yalçın, B., Tetik, S., Açıkgöz, A. (2010). Yüksekokul Öğrencilerinin Problem Çözme Becerisi Algıları İle Kontrol Odağı Düzeylerinin Belirlenmesine Yönelik Bir Araştırma, Organizasyon ve Yönetim Bilimleri Dergisi, 2(2), 19-27.

Yoldaş, C., Seven S. (2007). Sınıf Öğretmeni Adaylarının Sosyal Beceri Düzeylerinin İncelenmesi, Yüzüncü Yıl Üniversitesi, Eğitim Fakültesi Dergisi. Cilt:IV, Sayı:I, 1-18.

Yüksel, (2001). Öğretmenlerin Sahip Olmaları Gereken Davranış Olarak Sosyal Beceri, Milli Eğitim Dergisi, Mart, Nisan, Mayıs Sayısı, ss. 150.

Yüksel, G. (2004). Sosyal Beceri Envanteri, Ankara: Asıl Yayınevi. 
Yaşar Ekici, F. (2017). Okul öncesi öğretmen adaylarının problem çözme ve sosyal beceri düzeylerinin incelenmesi. International Journal of Social Sciences and Education Research, 3(1), 16-38.

\section{Extended Abstract in English}

Social skills are the abilities of an individual to behave in harmony with his or her emotional and sentimental constitution in interpersonal relationships. These are skills that enhance effective communication that enable an individual to cope with problems. Problem solving skills that enable an individual to find alternative ways to solve all of the problems related with all areas of life. For some professions having problem solving skills and having social skills can have more importance because individuals who posses these skills are more often better able to shape their professional identities and to benefit more from their professional institutions. One of such professions is teaching. Effective teachers have to be individuals whose problem solving skills are highly developed and who have a high level of social intelligence. In order to examine preservice preschool teachers' level of problem solving and social skills and to investigate relationship between level of problem solving and social skills of preservice preschool teachers this research was made. In this frame, these questions are tried to answer:

- Is there a significant difference between preservice preschool teachers' problem solving and social skill levels and age, grade, place stayed during education, income level, number of sibling?

- Is there a significant correlation between problem solving skills and social skills of preservice preschool teachers?

In the analysis of the data, SPSS 20 package program was applied. Kruskal Wallis H, Independent Sample t Test and Mann Whitney U was used for analysing data. At the end of the research, these results are found that:

- There is not a significant difference between preservice preschool teachers' problem solving skill levels and age, grade, place stayed during education, income level, number of sibling.

- There is not a significant difference between preservice preschool teachers' social skill levels and number of sibling.

- The level of social control skills of 18-20 age preservice preschool teachers is higher than he level of social control skills of 21-23 age and 33-35 age preservice preschool teachers

- The level of social control skills of 27-29 age preservice preschool teachers is higher than he level of social control skills of 24-26 age and 33-35 age preservice preschool teachers

- The level of social expression skills of preservice preschool teachers studying in 3.grade is higher than the level of social expression skills of preservice preschool teachers studying in 1. and 2.grade

- The level of general social skills of preservice preschool teachers staying in special dormitory is higher than the level of general social skills of preservice preschool teachers staying together with family and student home.

- The level of sensory expression skills of preservice preschool teachers staying in special dormitory and together with family is higher than the level of sensory expression skills of preservice preschool teachers staying in student home.

- The level of general social skills and sensory expression skills of preservice preschool teachers that have medium and high income level is higher than the level of general social skills and sensory expression skills of preservice preschool teachers that have low income level.

- There is not a significant correlation between problem solving skills and social skills of precervice preschool teachers. 